\title{
Avian neural crest cell migration is diversely regulated by the two major hyaluronan-binding proteoglycans PG-M/versican and aggrecan
}

\author{
Daniela Perissinotto ${ }^{1, *}$, Paola lacopetti ${ }^{1, *}$, Isabella Bellina ${ }^{1}$, Roberto Doliana ${ }^{1}$, Alfonso Colombatti ${ }^{1,2}$, \\ Zoé Pettway ${ }^{3}$, Marianne Bronner-Fraser ${ }^{3}$, Tamayuki Shinomura ${ }^{4}$, Koji Kimata ${ }^{4}$, Matthias Mörgelin ${ }^{5}$, \\ Jan Löfberg ${ }^{6}$ and Roberto Perris ${ }^{1,7, \neq}$ \\ ${ }^{1}$ The National Cancer Institute, CRO, IRCSS, Division for Experimental Oncology 2, Via Pedemontana Occidentale 12, \\ Aviano (PN) 33081 Italy \\ 2Department of Medical Science and Technology, University of Udine, 35100 UDINE, Italy \\ ${ }^{3}$ Division of Biology, California Institute of Technology, Pasadena, CA, USA \\ ${ }^{4}$ Institute for Molecular Science of Medicine, Aichi Medical University, Nagakute, AICHI, 480-11, Japan \\ ${ }^{5}$ Department of Cell and Molecular Biology, University of Lund, Box 94, S-22100 LUND, Sweden \\ ${ }^{6}$ Department of Environmental and Developmental Biology, University of Uppsala, S-75236 UPPSALA, Sweden \\ ${ }^{7}$ Department of Evolutionary and Functional Biology, University of Parma, 43100 PARMA, Italy \\ *These authors have contributed equally to the work \\ ¥Author for correspondence (e-mail: rperris@ets.it) \\ Accepted 11 April; published on WWW 13 June 2000
}

\section{SUMMARY}

It has been proposed that hyaluronan-binding proteoglycans play an important role as guiding cues during neural crest (NC) cell migration, but their precise function has not been elucidated. In this study, we examine the distribution, structure and putative role of the two major hyaluronan-binding proteoglycans, PG$\mathrm{M} /$ versicans and aggrecan, during the course of avian NC development. PG-M/versicans V0 and V1 are shown to be the prevalent isoforms at initial and advanced phases of $\mathrm{NC}$ cell movement, whereas the $\mathrm{V} 2$ and $\mathrm{V} 3$ transcripts are first detected following gangliogenesis. During NC cell dispersion, mRNAs for PG-M/versicans V0/V1 are transcribed by tissues lining the NC migratory pathways, as well as by tissues delimiting nonpermissive areas. Immunohistochemistry confirm the deposition of the macromolecules in these regions and highlight regional differences in the density of these proteoglycans. PG$\mathrm{M} /$ versicans assembled within the sclerotome rearrange from an initially uniform distribution to a preferentially caudal localization, both at the mRNA and protein level. This reorganization is a direct consequence of the metameric NC cell migration through the rostral portion of the somites. As suggested by previous in situ hybridizations, aggrecan shows a virtually opposite distribution to $\mathrm{PG}-\mathrm{M} /$ versicans being confined to the perinotochordal ECM and extending dorsolaterally in a segmentally organized manner eventually to the entire spinal cord at axial levels interspacing the ganglia. PG$\mathrm{M} /$ versicans purified from the $\mathrm{NC}$ migratory routes are highly polydispersed, have an apparent $M_{r}$ of 1,200-2,000 kDa, are primarily substituted with chondroitin-6- sulfates and, upon chondroitinase ABC digestion, are found to be composed of core proteins with apparent $M_{r}$ of 360-530,000. TEM/rotary shadowing analysis of the isolated PG-M/versicans confirmed that they exhibit the characteristic bi-globular shape, have core proteins with sizes predicted for the V0/V1 isoforms and carry relatively few extended glycosaminoglycan chains. Orthotopical implantation of PG-M/versicans immobilized onto transplantable micromembranes tend to 'attract' moving cells toward them, whereas similar implantations of a notochordal type-aggrecan retain both single and cohorts of moving NC cells in close proximity of the implant and thereby perturb their spatiotemporal migratory pattern. NC cells fail to migrate through threedimensional collagen type I-aggrecan substrata in vitro, but locomote in a haptotactic manner through collagen type I-PG-M/versican V0 substrata via engagement of HNK-1 antigen-bearing cell surface components. The present data suggest that PG-M/versicans and notochordal aggrecan exert divergent guiding functions during NC cell dispersion, which are mediated by both their core proteins and glycosaminoglycan side chains and may involve 'haptotactic-like' motility phenomena. Whereas aggrecan defines strictly impenetrable embryonic areas, PG-M/versicans are central components of the $\mathrm{NC}$ migratory pathways favoring the directed movement of the cells.

Key words: PG-M/versican, Neural crest, Cell migration, Aggrecan, Proteoglycan, Chick 


\section{INTRODUCTION}

It has been proposed that hyaluronan-binding (hyalectans) proteoglycans of large $M_{r}$ indiscriminately exert a negative influence during neural crest (NC) cell migration by functioning as spatially restricting molecules for the dispersing NC cells (Erickson and Perris, 1993; Henderson and Copp, 1997; Perris, 1997). In fact, xenographic transplantations of notochordal tissue in the vicinity of the neural tube inhibit cell movement locally and in a developmentally dependent fashion (Pettway et al., 1990, 1996), whereas ablation of the endogenous notochord causes abnormal ganglion formation (Teillet and Le Douarin, 1983; Tosney and Oakley, 1990; Stern et al., 1991). The observed effects seem to be imputable to its primary ECM proteoglycan, aggrecan, as shown by antibody blockade experiments and chondroitinase $\mathrm{ABC}$ digestions of the notochordal tissue implants (Pettway et al., 1990, 1996). These findings are also supported by the pronounced inhibitory effects of aggrecan on avian and amphibian NC cell motility in vitro (Perris and Johansson, 1987, 1989; Perris et al., 1991a, 1996; Kerr and Newgreen, 1997), and are further supported by the failure of ectopically introduced avian aggrecan to rescue migration of pigment cell precursors in the proteoglycandeficient white mutant embryo of the Mexican axolotl (Olsson et al., 1996).

Whereas these previous studies emphasize a negative influence of aggrecan on $\mathrm{NC}$ cell movement, the putative role of hyaluronan-binding PG-M/versicans remains ambiguous. Their patterned distribution within the somites (Tan et al., 1987; Landolt et al., 1995; Henderson et al., 1997) and the triggering of a precocious dorsolateral $\mathrm{NC}$ cell migration following surgical ablation of the dermomyotome (which is accompanied by an apparent reduction in chondroitin sulfatebearing proteoglycans deposited into the subectodermal space; Oakley et al., 1994), suggest that these proteoglycans could similarly function as potential 'barriers' for NC cell movement. However, it is unclear whether this patterned distribution is a cause, or a consequence, of the metameric $\mathrm{NC}$ cell migration within the sclerotome and it is not possible to preclude that the alteration in migratory behaviour of NC cells could be due to other morphogenetic anomalies caused by ablation of the dermomyotome tissue.

Two observations provide further contrasting data regarding the possible role of $\mathrm{PG}-\mathrm{M} / \mathrm{versicans}$ during $\mathrm{NC}$ development. First, the deficient expression of PG-M/versicans in the subectodermal region of the white mutant Mexican axolotl embryo is intimately associated with the failure of NC cells to migrate dorsolaterally (Perris et al., 1990; Stigson and Kjellen, 1991; Stigson et al., 1997a,b). Secondly, in the splotch $\left(S p^{2 H}\right)$ mouse mutant carrying abnormalities in the $\operatorname{Pax} 3$ gene (speculated to be a potential upstream regulator of the $P G$ $M /$ versican gene), aberrant expression of $\mathrm{PG}-\mathrm{M} / \mathrm{versicans}$ correlates with disturbed NC cell migration (Henderson et al., 1997). It should also be noted that deletion of the murine $P G$ $M /$ versican gene by insertional mutagenesis causes embryonic death due to abnormal heart chamber formation (Mjaavedt et al., 1998); this process is known to require the contribution of NC derivatives and substantial PG-M/versican deposition (Henderson and Copp, 1998).

PG-M/versicans, which are central ECM constituents in a number embryonic and adult tissues, have been characterized structurally and biochemically in several species (Kimata et al., 1986; Habuchi et al., 1986; Mörgelin et al., 1989; Morita et al., 1990; Perides et al., 1992; Yamagata et al., 1986, 1993; Shinomura et al., 1993; Carrino et al., 1994; DoursZimmermann and Zimmermann, 1994; Yao et al., 1996; Stigson and Kjellen, 1991; Stigson et al., 1997a; Schmalfeldt et al., 1998). Studies in avians, mice and man have established that at least four different isoforms can be generated by exon skipping from a larger transcript denoted V0 (Shinomura et al., 1993, 1995; Dours-Zimmermann and Zimmermann, 1994; Ito et al., 1995; Zako et al., 1995). Since these isoforms vary in the relative content of one or both of the two chondroitin sulfate-attachment domains, $\operatorname{CS} \alpha$ and $\operatorname{CS} \beta$, proteoglycans with entirely divergent functions could be expressed in different tissues and at different phases of development. Furthermore, the identification of an additional avian-specific spliced exon, analogous to that encoding the keratan sulfate-attachment domain of aggrecan (Zako et al., 1997), widens the repertoire of potential PG-M/versican isoforms and suggests that, in some tissues, these proteoglycans may carry keratan sulfate moieties.

In the present study, we have mapped the expression pattern of PG-M/versican isoforms and determined the in situ distribution of both PG-M/versicans and aggrecan during the course of NC cell development in the chick embryo. PG$\mathrm{M} / \mathrm{versicans}$ synthesized during the course of trunk NC cell movement were isolated, analyzed ultrastructurally and partially characterized immunochemically/biochemically. The potential function of PG-M/versicans and aggrecans in vivo and in vitro was then comparatively examined by implanting the purified molecules heteropically into the migratory pathways of the NC, via prior immobilization onto micromembranes and determining the capacity of cultured NC cells to migrate through three-dimensional collagen type Iproteoglycan substrata. The results are consistent with a predominant expression of the PG-M/versican V0 and V1 isoforms during early phases of avian embryonic development and point to diverse roles for PG-M/versicans and aggrecan during NC cell migration.

\section{MATERIALS AND METHODS}

\section{Purified mammalian and avian proteoglycans}

Hyaluronan-aggrecan complexes stabilized by link protein were purified from bovine nasal cartilage and cultured chondrosarcoma cells as described in Mörgelin et al., (1992). The chick cartilage aggrecan and the avian PG-M/versican V0 isoform were obtained from sternal cartilage from 12-days old chick embryos and cultured chick tendon fibroblasts, respectively, as previously described (Shinomura et al., 1983; Yamagata et al., 1986). Since according to our characterization (Perris et al., 1991a, 1996; data not shown) this aggrecan is structurally and immunologically identical to that expressed by the developing notochord (Domowicz et al., 1995), we refer to it as 'notochordal-like' aggrecan throughout the study. The bovine aorta PG-M/versicans V1/V2 were provided by Dick Heinegård (Department for Cell and Molecular Biology, University of Lund, Sweden) and purified in this study according to a novel purification scheme (M. Schiappacassi, D. P., S. Cattaruzza, P. Spessotto, A. C. and R. P., unpublished data). Previously published data (Kimata et al., 1986; Yamagata et al., 1986), and our recent ultrastructural and compositional analysis of the PG-M/versicans V0 isoform from cultured chick fibroblasts and V1/V2 isoforms from bovine aorta (Mörgelin et al., 1989; Perris et al., 1996; M. 
Table 1. Characteristics of anti-proteoglycan antibodies

\begin{tabular}{llll}
\hline Antibody & Immunogen (species) & \multicolumn{1}{c}{ Reactivity } & Epitope location \\
\hline MY174 & PG-M/versican V0 (avian) & PG-M/versicans & SPLICE domain ${ }^{1}$ \\
5D5 & PG-L2 (avian) & PG-L/PG-M/versicans V0-V2 & CS $\beta$ domain ${ }^{3}$ \\
2C12 & PG-M/versican V1/V2 (bovine) & PG-M/versicans V0-V2 & $N$-oligoS-Fuc ${ }^{4}$ \\
4G2 & PG-M/versican V1/V2 (bovine) & PG-M/versicans V0-V2 & $?$ \\
4C5 & PG-M/versican V1/V2 (bovine) & PG-M/versicans V0-V2 & Chondroitin-4-sulfate \\
5C12 & PG-M/versican V1/V2 (bovine) & PG-M/versicans V0-V2 & $N$-oligoS-Fuc \\
anti-PG-M (antiserum) & PG-M/versican V0 (avian) & PG-M/versicans & (whole molecule) \\
A1 (antiserum) & cartilage aggrecan (avian) & Aggrecan5 & (whole molecule) \\
CS56 & fibroblast ECM (avian) & chondroitin sulfates & domain 2
\end{tabular}

\footnotetext{
${ }^{1}$ According to the domain assignment of Shinomura et al. (1993)

${ }^{2}$ Refers to the high $M_{r}$ chondroitin/dermatan sulfate proteoglycan isolated from bovine sclera

${ }^{3}$ Reactivity and epitope locations were determined by biochemical and immunochemical means in conjunction with TEM/rotary shadowing using purified proteoglycans and recombinant proteins. These data are described in detail elsewhere (M. Schiappacassi, D. P., S. Cattaruzza, P. Spessotto, A. C. and R. P., unpublished data)

${ }^{4}$ The epitope resides in $\mathrm{N}$-linked oligosaccharides containing fucose residues at the non-reducing end. In chick embryonic PG-M/versicans these oligosaccharide moieties are susceptible to chondroitinase $\mathrm{ABC}$ digestion, whereas they are largely enzyme resistant in PG-M/versicans from bovine aorta (M. Schiappacassi, D. P., S. Cattaruzza, P. Spessotto, A. C. and R. P., unpublished data)

${ }^{5}$ Recognizes both the early notochordal and mature cartilage aggrecan

${ }^{6}$ According to the domain assignment of Sorrell et al. (1993)
}

Schiappacassi, D. P., S. Cattaruzza, P. Spessotto, A. C. and R. P., unpublished data), indicate substantial differences in the glycosaminoglycan chain composition of these proteoglycans: the former contains numerous, longer chains primarily composed of unusually oversulfated chondroitin-6-sulfate and some minor amounts of unsulfated and 4-sulfated chondroitin, whereas the latter have fewer, shorter chains mainly composed of chondroitin-4-sulfate and dermatan sulfate and no detectable amounts of unsulfated chondroitin and chondroitin-6-sulfate.

\section{Source and specificity of anti-proteoglycan antibodies}

The characteristics of the antibodies against proteoglycans used in this study are summarized in Table 1 . The previously indicated specificities of some of these antibodies were further ascertained here by ELISA, dot-blotting and western blotting utilizing a number of purified proteoglycans and recombinant fragments. mAb 5D5 (kindly provided by Firoz Rahemtulla, University of Alabama, Birmingham, AL) recognizes a highly conserved epitope shared by its immunogen, human (Perides et al., 1992), bovine (M. Schiappacassi, D. P., S. Cattaruzza, P. Spessotto, A. C. and R. P., unpublished data), avian (this study) and axolotl (not shown) PG$\mathrm{M} /$ versicans, but fails to react with aggrecan. The use of $\mathrm{CNBr}$ derived fragments of the fibroblast PG-M/versican V0 has previously shown that the epitope of mAb MY174 against avian PG$\mathrm{M} /$ versicans resides within chondroitin sulfate-free fragments ranging from 45-100 kDa (Yamagata et al., 1993). Our present data indicate that it recognizes a partially masked epitope on isoforms V0/V1 isoforms and/or PG-M/versicans with specific glycosylation traits. Specificity of the anti-avian PG-M/versican antiserum have been described elsewhere (Shinomura et al., 1993). The antiserum A1 (kindly provided by Maurizio Pacifici, Dental School, University Pennsylvania, Philadelphia, PA) reacts with early and late expressed chick notochordal aggrecan (Oettinger et al., 1985) and does not react with PG-M/versicans. mAbs $5 \mathrm{C} 12,4 \mathrm{G} 2,4 \mathrm{C} 5$ and $2 \mathrm{E} 12$ were generated by immunization of mice with the bovine aorta $\mathrm{PG}$ $\mathrm{M} /$ versicans $\mathrm{V} 1 / \mathrm{V} 2$ according to standard protocols. mAbs $5 \mathrm{C} 12$ and $2 \mathrm{C} 12$ react with $N$-linked oligosaccharides carrying terminal fucose residues that are present on $\mathrm{PG}-\mathrm{M} /$ versicans of various species and are susceptible to chondroitinase ABC digestion, whereas $\mathrm{mAb} 4 \mathrm{C} 5$ reacts with native chondroitin-4-sulfate. Further details about the production and specificity of these mAbs are reported elsewhere (M. Schiappacassi, D. P., S. Cattaruzza, P. Spessotto, A. C. and R. P., unpublished data). mAb CS56 against chondroitin sulfates was purchased from Sigma.

\section{RT-PCR and RNase protection assays (RPA)}

Since the precise location of the splice sites for V2 and V3 mRNAs are described for the mouse and human, but not for the chick $P G$ $M / v e r s i c a n$ gene, we aligned the mouse and chick nucleotide sequences and derived the corresponding avian splicing sites. The oligonucleotides synthesized for RT-PCR were:

AAG TTA ACC ACC CTT TTA CCT (PGM-A, sense), nucleotides 1432-1452;

TCA ACT GCT ACT GCA GTT G CAC (PGM-B, sense), nucleotides 4225-4246;

CAC TTG TTG CTT TCC ATT GAT G (PGM-C, antisense), nucleotides 4617-4638;

and $T$ GAG GCC ATC TAT ACA TGT GGC (PGM-D, antisense), nucleotides 10057-10078.

Exanucleotides were used to synthesize cDNA from total RNAs from midtrunk segments of stage 15-25 chick embryos using AMV Reverse Transcriptase (Promega). For the precise assessment of the developmentally related RNA expression levels of the V0-V3 transcripts by RPA, amplified and cloned riboprobes were linearized with the appropriate enzymes for the recombinant vectors and ${ }^{32} \mathrm{P}$ labelled antisense RNA riboprobes were synthesized from SP6 or T7 promoters with 20 units each of SP6 and T7 RNA polymerase (Promega), respectively, and annealed with $10-20 \mu \mathrm{g}$ of total RNA. RPA was carried using the RPA II kit (Ambion) according to the instructions provided by the supplier. Briefly, RNA was digested with $200 \mu \mathrm{l}$ of a RNase A/RNase T1 mixture (solution R) diluted 1:100 in RNase digestion buffer (solution $\mathrm{Bx}$ ) at $37^{\circ} \mathrm{C}$ for 30 minutes. The undigested fragments were precipitated by treatment with $300 \mu \mathrm{l}$ of Dx solution and cooling to $-20^{\circ} \mathrm{C}$ for 15 minutes. The fragments obtained were run on $5 \%$ polyacrylamide gel in the presence of $6 \mathrm{M}$ urea and visualized by autoradiography on Hyperfilm MP (Amersham). Calibration of the amount RNA loaded onto each lane was accomplished by independent agarose gel runs, using a chick $\beta$ actin probe as reference. Autoradiograms were produced at different exposure times; those in which the signal for the protected transcripts had reached saturation were photographed. Assessment of the relative levels of expression of the protected transcripts was accomplished by analyzing autoradiograms in the linear exposure range by computerassisted densitometry using a Philips CCD video camera and the GelScan software. Densities of the autoradiographic bands obtained for each individual isoform were plotted accounting for the specific intensities in ${ }^{32} \mathrm{P}$-activity of the differently sized fragments. Direct comparisons of the relative levels of expression of the individual isoforms at the given developmental stages are reported in per cent, 
adopting the signal obtained for the most abundantly expressed isoform as $100 \%$. The nature of the splicing sites permitted the direct comparison of the V0-V2 mRNA signals on the same autoradiogram, whereas the protected signal obtained for the V3 isoform was normalized to the one obtained in the same autoradiogram for the cumulative expression of V0-V2 mRNAs.

\section{In situ hybridization}

For radioactive and digoxigenin-based in situ hybridizations on whole embryos and tissue sections from embryos at developmental stages 15-23, a set of four cDNAs was employed. Since the largest V0 transcript encompasses all alternatively spliced exons, all cDNAs used in this study hybridize by default to this transcript, and hence, there is technically no possibility of discriminating between V0 and V1 when both transcripts are coexpressed. Riboprobe specificity was as follows.

\begin{tabular}{lcc}
\hline Riboprobe & Isoform specificity & Corresponding nucleotides \\
\hline M2a & V0, V2 & $2623-3810$ \\
M4a & V0, V1 & $7410-8406$ \\
M6a & V0, V1, V2, V3 & $9909-10827$ \\
M7a & V0, V1, V2, V3 & $10827-11649$ \\
\hline
\end{tabular}

cDNA probes were labelled with digoxigenin using the Boehringer Mannheim's DIG DNA labelling and detection kit according to the procedure indicated by the manufacturer. Whole-mount in situ hybridization was performed according to the protocol of Wilkinson (1992). For in situ hybridization on tissue sections, embryos were fixed in phosphate-buffered 4\% PFA for 4 hours to overnight at $4^{\circ} \mathrm{C}$, rinsed in PBS and incubated in 5\% sucrose for 1 hour at $4{ }^{\circ} \mathrm{C}$, followed by incubation overnight in $15 \%$ sucrose. Embryos were then embedded in OCT compound, cryosectioned and the sections were mounted on Super Frost slides, followed by air-drying, fixation in place with $4 \%$ PFA for 20 minutes at room temperature, dehydration through a graded series of ethanol and further air-drying. The prehybridization procedure involved a rehydration of the sections and treatment with $3 \mu \mathrm{g} / \mathrm{ml}$ proteinase $\mathrm{K}$ in $10 \mathrm{mM}$ Tris- $\mathrm{HCl}$, $\mathrm{pH}$ 8.0, with $2 \mathrm{mM}$ EDTA, for 15 minutes at $37^{\circ} \mathrm{C}$. Sections were then washed in PBS, fixed in 4\% PFA for 20 minutes at room temperature, rewashed and incubated for 10 minutes in $0.1 \mathrm{M}$ triethanolamine, $\mathrm{pH} 8.0$, followed by acetylation with $0.25 \%$ acetic anhydride for 15 minutes at room temperature. Sections were then washed in PBS and prehybridized in $300 \mu \mathrm{l}$ of $1 \mathrm{ml}$ hybridization solution composed of $100 \mu \mathrm{M}$ Tris- $\mathrm{HCl}, \mathrm{pH} 7.5$, with $0.15 \mathrm{M} \mathrm{NaCl}, 500 \mu \mathrm{l}$ formamide, 200 $\mu \mathrm{l}$ of $20 \times \mathrm{SSC}, 20 \mu \mathrm{l}$ of $50 \times$ Denhardt's solutions, $50 \mu \mathrm{l}$ of heatdenatured herring sperm DNA $(10 \mathrm{mg} / \mathrm{ml}), 25 \mu \mathrm{l}$ of yeast tRNA $(10$ $\mathrm{mg} / \mathrm{ml}$ ) and $200 \mu \mathrm{l} 50 \%$ dextran sulfate solution for 3-5 hours at room temperature in a humidified chamber. For hybridization, DIG-labelled or $\left[{ }^{35} \mathrm{~S}\right] \mathrm{UTP}$-labelled, heat-denatured riboprobes were dissolved at 0.2 $\mu \mathrm{g} / \mathrm{ml}$ in hybridization solution and applied to the sections for $18-20$ hours at $55^{\circ} \mathrm{C}$. Thereafter, sections were sequentially incubated in $5 \times$ SSC for 30 minutes at $55-60^{\circ} \mathrm{C} ; 2 \times \mathrm{SSC}$ containing $50 \%$ formamide for 20 minutes at $50-55^{\circ} \mathrm{C}, 4 \times \mathrm{SSC}$ for 10 minutes at $37^{\circ} \mathrm{C}$; $4 \times \mathrm{SSC}$ containing $20 \mu \mathrm{g} / \mathrm{ml}$ RNase A for 30 minutes at $37^{\circ} \mathrm{C} ; 4 \times \mathrm{SSC}$ for 10 minutes at $37^{\circ} \mathrm{C} ; 2 \times \mathrm{SSC} / 50 \%$ formamide for 20 minutes at $55^{\circ} \mathrm{C} ; 2 \times$ SSC for 15 minutes at $37^{\circ} \mathrm{C}$; and finally $0.1 \times$ SSC for 15 minutes at $37^{\circ} \mathrm{C}$. Hybridized DIG-labelled probes were visualized using the DIG detection kit, whereas sections hybridized with radioactive probes were rinsed for 2 hours at $50^{\circ} \mathrm{C}$ in hybridization buffer, digested with RNase A for 30 minutes at $37^{\circ} \mathrm{C}$, washed, air-dried and dipped in NTB-2 emulsion (Kodak; diluted 1:1 in $\mathrm{H}_{2} \mathrm{O}$ ). Sections were then exposed for different time periods at $4^{\circ} \mathrm{C}$, developed, fixed and mounted in DPX mounting medium.

\section{Purification of PG-M/versicans from NC migratory pathways}

Embryos at stages 15-23 were explanted into Pannett-Compton solution and 8- to 10-somite-long segments from the trunk region extending from the wing bud to the hindlimb were excised, further trimmed to remove the developing gut and pronephric ducts, and immediately frozen in liquid $\mathrm{N}_{2}$. Explanted tissues were gently homogenized on ice and extracted for $20-24$ hours at $4^{\circ} \mathrm{C}$ with $4 \mathrm{M}$ GuHCl, $50 \mathrm{mM}$ acetate buffer, $\mathrm{pH} 5.8$, containing $1 \mathrm{mM}$ PMSF, 10 mM NEM, $10 \mathrm{mM}$ caproic acid, $10 \mathrm{mM}$ benzamidine, $10 \mathrm{mM}$ EDTA and $0.2 \%$ Triton X-100. The extract was centrifuged at $14,000 \mathrm{~g}$ for 40 minutes and the supernatant was collected, dialyzed against $50 \mathrm{mM}$ Tris- $\mathrm{HCl}$, pH 8.0, containing $7 \mathrm{M}$ urea, $2 \mathrm{mM} \mathrm{MgCl}_{2}, 0.2 \%$ Triton X100 and the same protease inhibitors, and digested with $50 \mu 1$ benzoase (Boehringer Mannheim) for 1 hour at $37^{\circ} \mathrm{C}$. The digest was then redialyzed and loaded onto a Sephadex G-50 column, which was directly connected to DEAE-Sepharose Fast Flow column (Amersham-Pharmacia). After loading of the sample, the two columns were disconnected and the DEAE-Sepharose column was washed with 5 volumes of washing buffer composed of $50 \mathrm{mM}$ Tris- $\mathrm{HCl}, \mathrm{pH}$ 8.0, $7 \mathrm{M}$ urea, $0.4 \mathrm{M} \mathrm{NaCl}, 5 \mathrm{mM}$ EDTA, $10 \mathrm{mM}$ aminocaproic acid and $10 \mathrm{mM}$ benzamidine. The column was then eluted with $6 \mathrm{M}$ $\mathrm{GuHCl}$ in $50 \mathrm{mM}$ acetate buffer, $\mathrm{pH} 5.8,50 \mathrm{mM}$ EDTA, $0.1 \%$ Triton $\mathrm{X}-100$ and the cocktail of protease inhibitors. Fractions containing the proteoglycans of interest were selected by ELISA, or filtration dotblot assays in the Easy-Titer ELIFA device (Pierce), according to the protocols indicated by the manufacturer and using mAbs 5D5, MY174 and CS56. The immunoreactive fractions were pooled and loaded onto CL-2B Sepharose columns equilibrated with Tris-urea washing buffer and eluted with the same buffer. In a separate set of experiments, analytical CL-2B Sepharose gel permeation chromatograms were run on extracts derived from $\sim 100$ embryo explants for each of the developmental stages 15, 17 and 23. Eluted fractions were analyzed by ELISA, dot-blot, SDS-agarose gel electrophoresis, involving Alcian blue-silver staining (see below) and western blotting with the above indicated mAbs. In these latter two cases, single fractions, or pools of PG-M/versican-containing fractions identified by ELISA/dot-blot, were precipitated with ethanol $(1: 9 \mathrm{v} / \mathrm{v})$ in the cold and resuspended in sample buffer for electrophoretic separation. Preparative purifications of PG-M/versicans were carried out on extracts of trunk segments from 150-300 embryos at stages $17-18$ by collecting the 5D5-positive proteoglycan pool obtained by gel permeation chromatography on CL-2B Sepharose and by loading the eluate onto DEAE-Sepharose columns $(20 \mathrm{ml})$. These were then eluted with a linear $0.3-2.0 \mathrm{M} \mathrm{NaCl}$ gradient in $20 \mathrm{mM}$ Tris- $\mathrm{HCl}, \mathrm{pH}$ 8.0, $7 \mathrm{M}$ urea. Proteoglycans separated by the $\mathrm{NaCl}$ gradient were examined by ELISA/dot-blot, SDS-PAGE, SDS-agarose gel electrophoresis and western blotting using the anti-PG-M antiserum, and mAbs 5D5, MY174, 2C12 and 5C12. These PG-M/versican preparations were also used for coating of micromembranes to be implanted into embryos (see below). Fractions containing PG$\mathrm{M} /$ versicans recognized by $\mathrm{mAb} 5 \mathrm{D} 5$ and the anti-PG-M/versican antiserum were also pooled, dialyzed against $10 \mathrm{mM}$ piperazine/perchlorate buffer, $\mathrm{pH} 5.0$, containing $6 \mathrm{M}$ urea and $0.1 \%$ CHAPS and further by chromatographed on a Mono-Q column eluted with a linear $0-0.5 \mathrm{M}$ gradient of $\mathrm{LiClO}_{4}$ in the same buffer. Eluted fractions were analyzed as indicated above.

\section{SDS-PAGE, SDS-agarose gel electrophoresis and western blotting}

Purified embryonic PG-M/versicans were analyzed in their intact form by agarose gel electrophoresis, in the presence of SDS according to a previously described procedure (Perris et al., 1996). Resolved proteoglycans were visualized by combined silver and Alcian blue staining according to the procedure of Min and Cowman (1985), and further examined by western blotting using the panel of antiproteoglycan antibodies (Table 1). PG-M/versicans were also resolved either intact, or after single and combined enzymatic digestions by SDS-PAGE on gradient 3-8\% gels, under reducing and non-reducing conditions, and similarly analyzed by western blotting. For enzymatic 
predigestions, proteoglycan-containing fractions were dialyzed against $50 \mathrm{mM}$ Tris- $\mathrm{HCl}, \mathrm{pH} 7.6$ (chondroitinase ABC, ACII and heparitinase), or $50 \mathrm{mM}$ sodium acetate buffer, $\mathrm{pH} 5.8$ (keratanase I and endo- $\beta$-galactosidase), and alternatively digested for 1 hour at $37^{\circ} \mathrm{C}$ with $0.3 \mathrm{U} / \mathrm{ml}$ of chondroitinase $\mathrm{ABC}, 0.3 \mathrm{U} / \mathrm{ml}$ of chondroitinase ACII, $0.01 \mathrm{U} / \mathrm{ml}$ of keratanase $\mathrm{I}, 0.01 \mathrm{U} / \mathrm{ml}$ of endo- $\beta$ galactosidase and $0.02 \mathrm{U} / \mathrm{ml}$ of heparitinase III (Sigma). For western blotting, PG-M/versicans resolved by SDS-PAGE, or SDS-agarose electrophoresis, were electrolytically transferred onto nylon (Zeta Probe, Bio-Rad), PVDF (Millipore) or nitrocellulose (Schleicher \& Schuell) membranes in standard transfer buffer at $\mathrm{pH} 6.5$ for agarose gels and $\mathrm{pH} 9.0$ for polyacrylamide gels. Membranes were saturated with $4 \% \alpha$-casein in $0.1 \mathrm{M}$ bicarbonate buffer, $\mathrm{pH} 8.8$, containing $1 \%$ PVP 40,000 (Sigma) and $10 \mathrm{mM}$ EDTA for 2-12 hours at room temperature, and incubated with primary antibodies diluted in the same solution as above, but with $1 \% \alpha$-casein and $0.15 \mathrm{M} \mathrm{NaCl}$, to 1:1 (for supernatants) or 1:1,000 for ascites fluids and purified IgGs. After extensive washings with the antibody-incubation buffer supplemented with $0.3 \%$ Tween-20, membranes were further incubated with secondary antibodies at 1:1,000 for 1 hour at room temperature, washed and processed for chemiluminescence using the ECL-Plus chemiluminescence kit (Amersham-Pharmacia). Apparent $M_{r}$ s above the 205,000 band of myosin II were determined in parallel run Coomassie-blue-stained gels containing reduced and nonreduced EHS laminin-1 ( $\sim 400 \mathrm{kDa}$ for the $\alpha 1$ chain reduced; $\sim 1,000 \mathrm{kDa}$ for the nonreduced heterotrimer), intact collagen type VI tetramers $(\sim 2,400 \mathrm{kDa})$, a purified IgM-class mouse immunoglobulin $(950$ $\mathrm{kDa}$ ), and gel electrophoresis/gel filtration standards (Sigma), comprising thyroglobulin $(669 \mathrm{kDa})$, ferritin $(440 \mathrm{kDa}), \beta$-catalase $(232 \mathrm{kDa})$, lactate dehydrogenase $(140 \mathrm{kDa}), \beta$-galactosidase $(106$ $\mathrm{kDa})$, phosphorylase $(97 \mathrm{kDa})$ and BSA (67 kDa).

\section{TEM and rotary shadowing}

For TEM involving rotary shadowing, proteoglycan samples (final concentration of $10 \mu \mathrm{g} / \mathrm{ml}$ ) were dialyzed overnight against $0.2 \mathrm{M}$ ammonium hydrogen carbonate, $\mathrm{pH} 7.9$, in a microdialysis apparatus (5-50 $\mu 1$, Biowerk), mixed with an equal volume of $80 \%$ glycerol and prepared for ultrastructural analysis as previously described (Mörgelin et al., 1989, 1992). Specimens were dried at high vacuum for 1-2 hours and rotary shadowed at a $9^{\circ}$ angle with platinum/carbon, followed by coating with carbon at a $90^{\circ}$ angle. Replicas were floated onto distilled water and picked up on 400-mesh copper grids. Electron micrographs were taken on a Zeiss 10 transmission electron microscope operated at $80 \mathrm{kV}$ accelerating voltage. Magnifications $(\times 25,000)$ were calibrated by photography of a calibration grid (Balzers) under the same electron optical conditions. Measurements were performed on a screen after $\times 10$ enlargement of the negatives. For ultrastructural analysis of the NC cell-proteoglycan interaction in vivo, embryos that had received proteoglycan-coated micromembranes were processed for TEM as previously described (Perris et al., 1990).

\section{Immunohistochemistry}

Since optimal staining with the various anti-proteoglycan antibodies required different fixation and embedding procedures, embryos at developmental stages 15-24 were processed according to the requirement of each antibody to be used. Thus, sections were prepared from freeze-substituted and paraffin-embedded embryos as previously described (Perris et al., 1991a), or from embryos fixed with $4 \%$ paraformaldehyde for 1 hour at room temperature followed by quick freezing in liquid $\mathrm{N}_{2}$ and embedding in OCT compound. Enzymatic pretreatments with either testicular hyaluronidase and/or collagenases did not alter the immunoreactive pattern observed (not shown). Double immunolabellings with the antiserum A1 and antibody HNK1 , or mAb CS56 and the biotinylated HNK-1 antibody, were carried out using appropriate affinity-purified secondary antibodies and FITC-, BODIPY- or Texas Red-conjugated streptavidin (Amersham-
Pharmacia). Another series of double-labellings were performed with the anti-PG-M/versican antiserum and the HNK-1 antibody on sections from embryos in which the $\mathrm{NC}$ had been locally ablated by surgical removal of the neural folds (Perris et al., 1991b).

\section{Implantation of purified proteoglycans bound to micromembranes}

Nucleopore polycarbonate circular sheets (13 $\mathrm{mm}$ in diameter; Costar) with a pore size of $1-3 \mu \mathrm{m}$, which is by far larger than that allowing free passage of migrating NC cells (Newgreen, 1989), were incubated overnight at $4^{\circ} \mathrm{C}$, or for 4 hours at $37^{\circ} \mathrm{C}$, with human plasma fibronectin (Collaborative Biochemical Products), the chick notochordal-like aggrecan, multimeric hyaluronan-aggrecan complexes from bovine nasal cartilage, the avian PG-M/versican V0, the bovine aorta PG-M/versicans V1/V2, or PG-M/versicans V0/V1 purified from stage 22 chick embryonic trunks. In some cases, the chick aggrecan was digested with chondroitinase ABC (Sigma) alone, or with both chondroitinase $\mathrm{ABC}$ and endo- $\beta$-galactosidase (Sigma), as previously described (Perris et al., 1996), and subsequently coated onto the micromembranes. Since these are porous and they were entirely immersed into the protein solution during coating, the molecules were unavoidably adsorbed onto both sides of the membranes. Relative coating efficiency was ascertained qualitatively by indirect immunohistochemistry on micromembranes in vitro, or on tissue sections derived from embryos that had received micromembrane implants (not shown), and quantitatively by using ${ }^{3} \mathrm{H}$-labelled fibronectin, the notochordal-like aggrecan and a bovine nasal cartilage aggrecan. In this latter case, the amount of protein bound to the micromembranes was estimated to be $0.2-0.4 \mathrm{pmol} / \mathrm{cm}^{2}$, at a coating concentration of $1,000 \mu \mathrm{g} / \mathrm{ml}$ and assuming the $M_{r}$ of 440,000 and 240,000, respectively, for fibronectin and the proteoglycans' core proteins. Comparable coating efficiencies were also detected for aggrecans, avian PG-M/versican V0 and bovine PG$\mathrm{M} /$ versican V1/V2 by solid-phase binding assays using biotinylated molecules (data not shown). Micromembranes measuring approximately $300 \times<100 \mu \mathrm{m}$ prepared from coated and uncoated membranes were extensively rinsed in Howard's Ringer solution and surgically implanted into various regions of the trunk at the level of the last 4-6 somites formed. Embryos were excised from the egg, rinsed in Pannett-Compton solution, fixed in Zenker's fixative, paraffin embedded and serially sectioned as previously described (Pettway et al., 1990). Sections were processed for indirect immunofluorescence using the HNK-1 antibody and analyzed in either a Leitz Axiovert microscope or a computer-interfaced Bio-Rad MCR 1024/Nikon Diaphot confocal laser microscope equipped with the apposite image acquisition and analysis softwares.

\section{Migration assay in vitro}

NC cultures and preparation of fibronectin- and proteoglycancontaining polymeric collagen type I (Col I) substrata in a delimited area ( 1 cm in diameter) of a $35 \mathrm{~mm}$ tissue culture dish (Nunc) were carried out as previously described (Perris et al., 1991b, 1993). For the generation of Col I polymers comprising of 'homogeneous' concentrations of the chick PG-M/versican V0 or aggrecan, $300 \mu \mathrm{l}$ of a $600 \mu \mathrm{g} / \mathrm{ml}$ solution of rat tail Col I (Collaborative Biochemical Products) was diluted in MEM containing 5\% fibronectin-depleted FCS (Gibco/BRL) and the proteoglycans were incorporated into the polymerizing collagen solution at concentrations of $10-500 \mu \mathrm{g} / \mathrm{ml}$. For production of Col I polymeric substrata containing stepwise increasing or decreasing amounts of the PG-M/versican V0 isoform, multiple overlying layers, each containing $10,50,100$ or $500 \mu \mathrm{g} / \mathrm{ml}$ of the proteoglycan, were prepared using $150 \mu \mathrm{l}$ of total collagenproteoglycan solution for polymerization of each layer. Neural tubeneural crest explants, or isolated NC cells, were embedded into the collagen polymer by being resuspended in $50 \mu \mathrm{l}$ of unpolymerized Col I solution, with and without HNK-1, 5D5 or CS56 antibodies at an Ig concentration of $20-70 \mu \mathrm{g} / \mathrm{ml}$. The solution was then aliquoted 

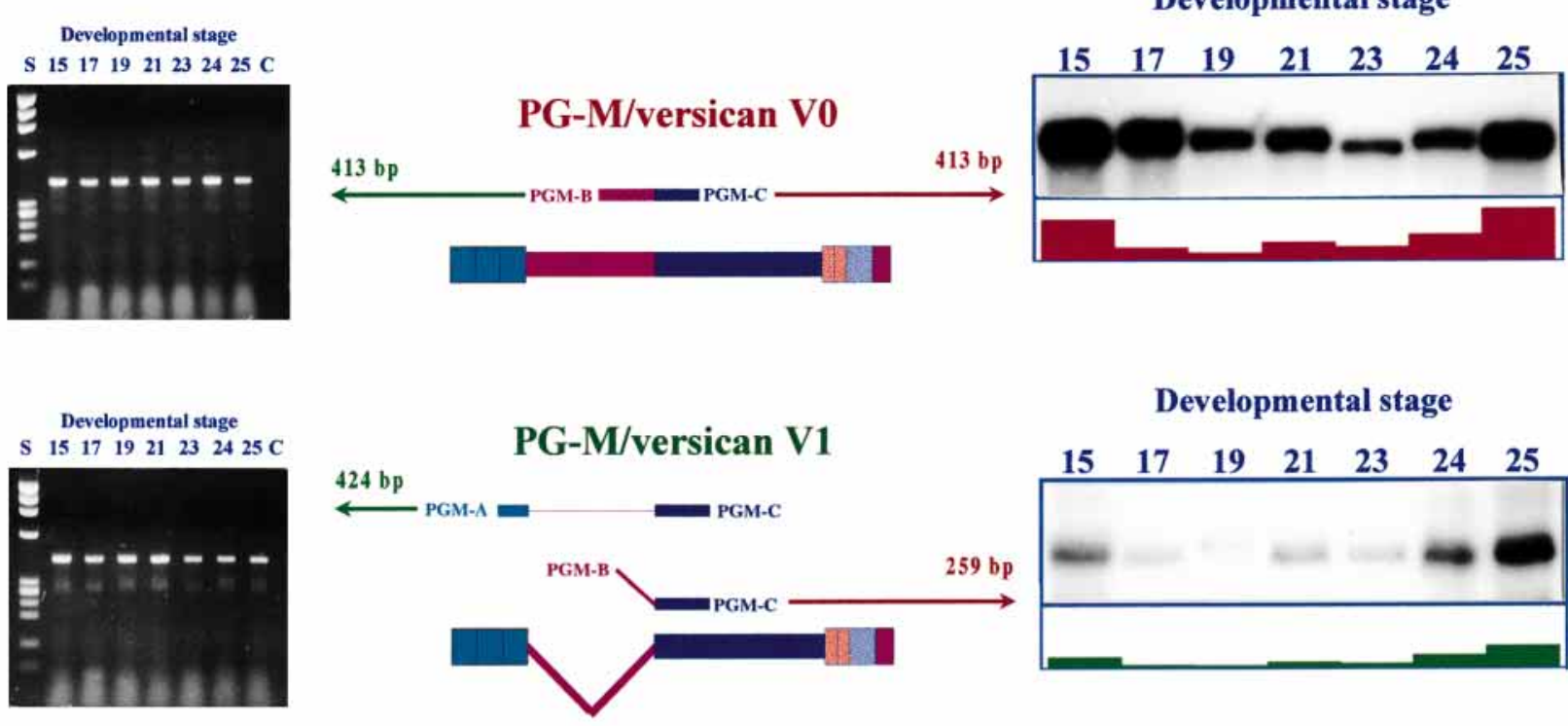

\section{Developmental stage}
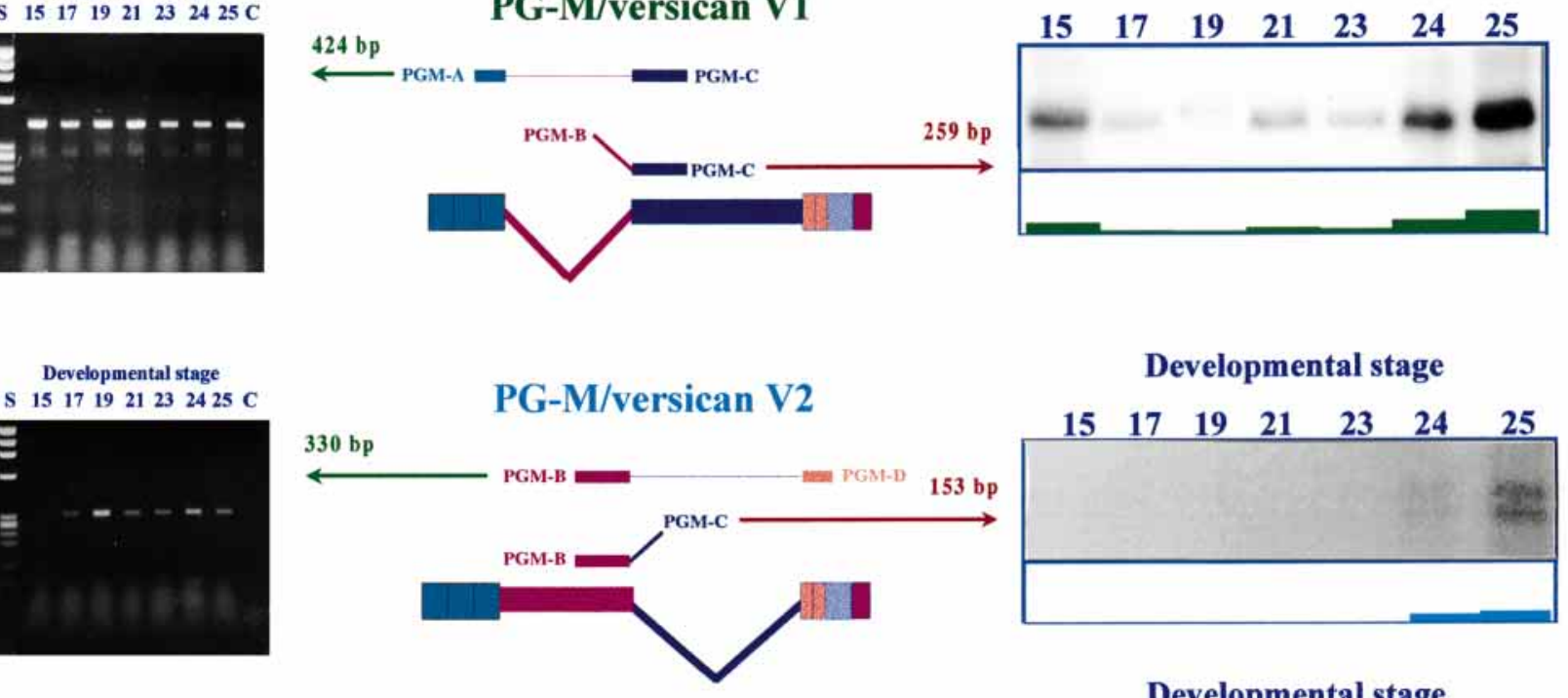

Developmental stage
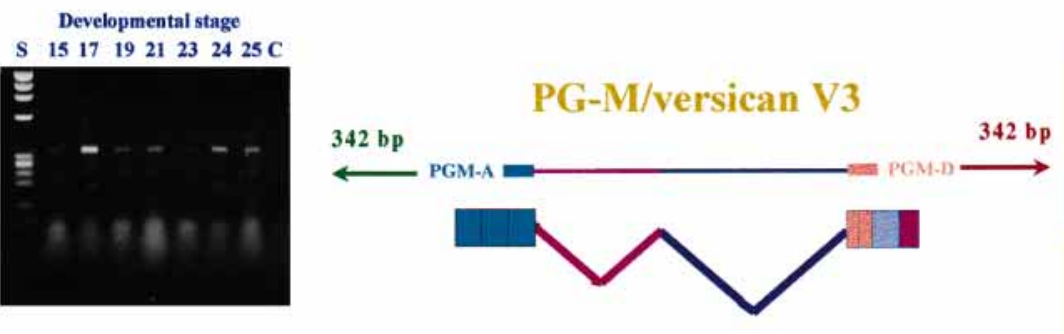

$\begin{array}{lllllll}15 & 17 & 19 & 21 & 23 & 24 & 25\end{array}$

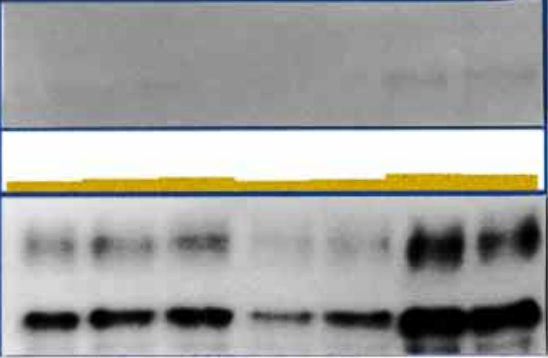

Fig. 1. Qualitative and quantitative analysis of the expression levels of PG-M/versican V0-V3 transcripts during various phases of NC development, i. e. developmental stages 15-25. (Left panels) Temporal expression of PG-M/versicans during the course of NC development detected by RT-PCR; (right panels) corresponding quantitative mapping as determined by RPA. Numbers above the arrows indicate the size of the amplified versus protected fragments. The comparative expression levels of the V0-V2 transcripts could be assessed in the same autoradiogram, whereas the temporal expression levels of the V3 mRNA were determined by comparing the signals obtained for the protected V3 fragment with the signals obtained cumulatively for the V0-V2 mRNAs.

onto the final substratum and further polymerized for 1-2 hours at $37^{\circ} \mathrm{C}$. The depth of NC cell invasion into the polymeric Col I substrata was established under an inverted Nikon Diaphot microscope after 1620 hours by estimating the plane at which the three most advanced cells localized and using transparent calibration devices of known thickness and the micrometric scale of the microscope focusing knob. The data are reported in arbitrary units derived from these measurements. Complementary video time-lapse recordings and velocity measurements of $\mathrm{NC}$ cell movement through the threedimensional substrata were performed as previously described (Perris et al., 1993).

\section{RESULTS}

\section{Expression of PG-M/versican V0-V3 mRNAs}

Using sequence alignments of the chick, mouse and human $P G-M / v e r s i c a n$ genes to pinpoint the splicing sites, four primers, denoted PGM-A, PGM-B, PGM-C and PGM-D, were designed that would discriminate between $\mathrm{PG}-\mathrm{M} /$ versicans V0-V3 transcripts. RT-PCR was initially used to study the expression of these transcripts at various developmental stages. Equivalently strong amplified products were obtained for V0 
and $\mathrm{V} 1$ at all developmental stages examined, indicating that these mRNAs were transcribed at high levels early in development (Fig. 1). Further quantification of the temporal mRNA expression by RPA showed that V0 was the predominant $P G-M / v e r s i c a n$ transcript expressed during the course of NC development, whereas V2 and V3 mRNAs were barely detectable and estimated to be $\geq 100$-fold less abundant that the parent V0 mRNA.

Overexposure of the RPA autoradiograms revealed that the initially poor $\mathrm{V} 2$ and $\mathrm{V} 3$ mRNA transcription markedly increased by stages 24-25. Due to the relatively larger size of the protected V3 fragment yielding a greater intrinsic radioactivity, a weak and fluctuating V3 signal could be detected throughout NC cell migration (Fig. 1). Assuming equivalent hybridization efficiency for the V2 and V3 riboprobes, the temporal expression levels of the V3 transcript, assessed by densitometric analysis of the autoradiograms after proper correction for the size difference of the protected fragments, appeared somewhat lower than of the V2 (Fig. 1). In contrast, the temporal expression patterns of the V0 and V1 mRNAs were closely similar, being elevated at stages prior to the onset of $\mathrm{NC}$ cell migration and showing a rapid decline during the course of cell movement and the formation of the peripheral nervous ganglia. When NC cell movement and maturation of the peripheral nervous structures was complete, V0 and V1 mRNA transcription was upregulated and this increased mRNA expression coincided with the initial transcription of the V2 mRNA (Fig. 1).

Whole-mount and tissue section in situ hybridizations with four different cDNA probes (Fig. 2A) indicated that, just prior to the onset of NC cell migration (stage 15), the weak V0/V1 transcription occurred primarily in the ectoderm, neural tube and notochord, whereas little or no expression of these mRNAs could be detected within the somites (not shown). In contrast, a clearly positive signal could be observed in the ectoderm, neural tube, notochord, ventral portion of the sclerotome, dorsal dermomyotome and the periaortic regions, at stages of advanced NC cell movement, (stages 17-18; Fig. 2B,C). PG$\mathrm{M} /$ versican expression was particularly pronounced in the floor plate, the mesonephric ducts, wing and limb bud mesenchymes, and the lateral plate non-segmented mesoderm. Whole-mount hybridization revealed a rather uniform sclerotomal distribution at trunk axial levels corresponding to regions of active $\mathrm{NC}$ cell movement, whereas more anterior axial levels had a PG-M/versican expression displaced to the caudal portion of the sclerotome. PG-M/versicans were also widely expressed in cranial regions containing actively moving/differentiating NC cells (Fig. 2D).

During the final phases of trunk NC cell dispersion, PG$\mathrm{M} /$ versican mRNA transcription became markedly polarized within the sclerotome, being concentrated in its more ventral regions, and within the notochord, where it accumulated in its dorsal half (Fig. 2D,E). In the neural tube, PG-M/versican transcription became gradually displaced to its luminal side (Fig. 2E). At stages of gangliogenesis, PG-M/versican expression along the body axis was fully metameric (Fig. 2F), as seen in whole-mount hybridizations of aggrecan and link protein (Kenny and R. P., unpublished data), and was also seen in the aggregated sensory ganglia (Fig. 2G), and was presumably associated with Schwann cells and other supporting glial cells. A further polarization of PG-M/versican
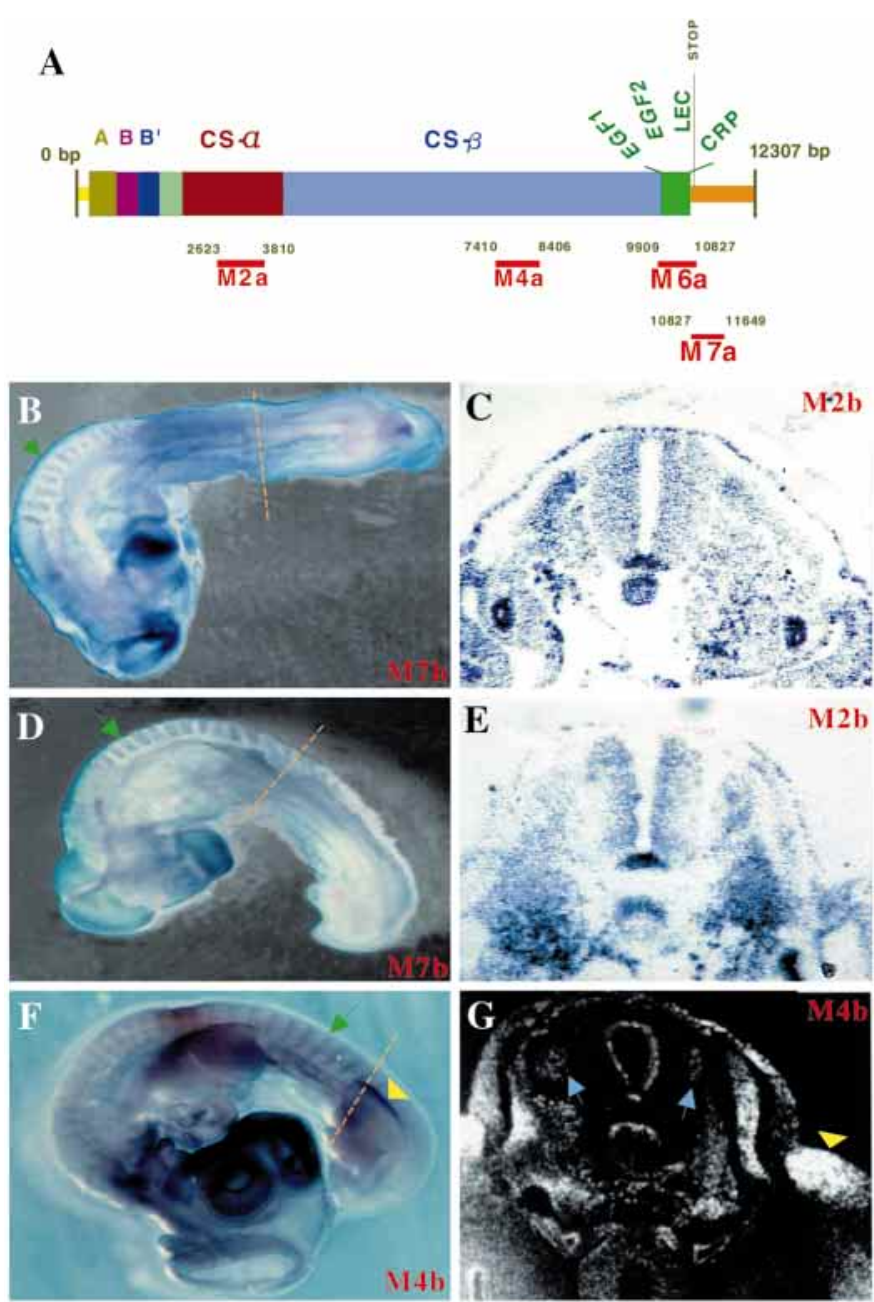

Fig. 2. (A-G). Whole-mount (B,D,F) and tissue section (C,E,G) in situ hybridizations with the indicated PG-M/versican cDNAs probes. (A) V0 domain structure, according to Shinomura et al., (1993), and the relative position of the cDNA probes used in this study (sense orientation indicated by the suffix ' $a$ ' and antisense by ' $b$ '). CS $\alpha$ and $\mathrm{CS} \beta$ denote the glycosaminoglycan-attachment domains, which are deleted in the V1 and V2 isoforms, respectively, whereas V3 lacks both these domains (compare with Fig. 1). M6b corresponding to the highly conserved $5^{\prime}$ globular domain was found to cross-hybridize with the aggrecan gene. The other probes were found to yield equal hybridization efficiency and were used interchangeably. Dashed lines in orange indicate the approximate trunk level represented by the tissue sections in C, E and G. Green arrows, the metameric distribution of PG-M/versican mRNA gradually established in a rostral-to-caudal sequence; yellow arrowheads, strongly positive ectodermal-mesenchymal ridges at level of the wing and limb buds; light blue arrows, a sensory ganglion exhibiting PG-M/versican expression. Note the progressive exclusion of PG-M/versican expression in the presumptive chondrogenic areas, i. e. perinotochordal area and lateral neural tube (Fig. 5). Developmental stages, (B,C) stage 17; (D,E) stage 19; (F,G) stage 23.

expression was noted at these stages within the neural tube, becoming confined to the luminal portion and excluded from the marginal zone. PG-M/versican expression strongly diminished in the floor plate, notochord (being solely present in a dorsal rim), and medial ventral sclerotome at axial levels of the ganglia, whereas it was still pronounced at intermediary 
axial levels (Figs 2G and 3D-F). PG-M/versican expression remained absent from the developing myotomes, but was intensified in the periaortic region, developing dermis and the mesenchyme lining the developing gut. Strong expression was observed in the ectodermal layer of the limb and wing buds, as well as throughout the prechondrogenic mesenchyme of these structures (Fig. 2G; Kimata et al., 1986; Yamagata et al., 1993).

\section{Tissue distribution of PG-M/versicans, aggrecan and their putative glycosaminoglycan moieties}

At stages preceding and concurrent with the onset of NC cell migration, staining with anti-PG-M/versican antibodies was prominent in the subectodermal space, around the neural tube and the notochord and, in addition, some punctate staining could be observed within the epithelial somites (Fig. 3A). In contrast, the anti-chick aggrecan antiserum was only weakly reactive with the perinotochordal membrane (not shown). Immunolabellings with anti-PG-M/versican antibodies largely coincided with that previously seen with antibodies to high-to-oversulfated chondroitin-6-sulfate, whereas the staining pattern observed with the anti-aggrecan antiserum A1 largely corresponded to that previously reported with a number of anti-keratan sulfate, antichondroitin-4-sulfate and anti-unsulfated chondroitin antibodies (Perris et al., 1991a; Perris, 1997), as well as that observed here with the novel anti-native chondroitin-4-sulfate $\mathrm{mAb} 4 \mathrm{C} 5$ and $\mathrm{mAb} 4 \mathrm{G} 2$ (Table 1). These patterns were maintained throughout the course of $\mathrm{NC}$ cell migration (stages 17-20; Fig. 3B,C). Double labelling with the CS56 and HNK-1 antibody clearly showed that NC cells invading the rostral sclerotome did so by entering a PG-M/versicanrich ECM, which was progressively displaced to the caudal portion of the sclerotome (Fig. 4A). Similar HNK-1/antiserum A1 double labellings also demonstrated that $\mathrm{NC}$ cells migrating ventrolaterally toward presumptive neuronal sites progressed at a considerable distance from the aggrecan-rich perinotochordal ECM (Fig. 4D,E). Conversely, the aggrecan-free but PG-M/versicanrich subectodermal space was not found to constitute a transiently impenetrable 'barrier' for dispersing NC cells since some early migrating cells were fully capable of invading this region (Fig. 3F).

To ascertain whether the previously reported distribution of chondroitin sulfate-bearing proteoglycans in the caudal portion of the somites (Tan et al., 1987; Landolt et al., 1995; Henderson et al., 1997) could be attributed to a predefined organization of PG-M/versicans or whether it was dependent upon the regional movement of the cells (Perris, 1997), a portion of the premigratory NC was ablated and the sclerotomal PG-M/versican distribution was examined in somites largely lacking migrating NC cells. Single and combined stainings with the HNK-1 antibody and the anti-
PG-M/versican antiserum showed that distribution of these proteoglycans remained uniform within the somites deprived of invading $\mathrm{NC}$ cells. In contrast, PG-M/versicans were excluded from the somitic regions occupied by migrating cells in the adjacent unoperated axial levels (Fig. 4A-C).

Following formation of the peripheral nervous ganglia, PG$\mathrm{M} /$ versicans were widespread throughout the sclerotome, within the subectodermal space, and in the perinotochordal and periaortic regions (Fig. 3D-F). Immunostainings with $\mathrm{mAb}$ MY174 revealed a particularly intense deposition of PG$\mathrm{M} /$ versicans in the perinotochordal/periaortic areas and a definite exclusion of these proteoglycans from the NC-derived sensory ganglia, the ventral axonal bundles and the developing myotomes (Fig. 3F). Similar staining patterns were observed with mAbs $5 \mathrm{C} 12$ and $2 \mathrm{C} 12$, whereas mAbs $4 \mathrm{C} 5$ and $4 \mathrm{G} 2$
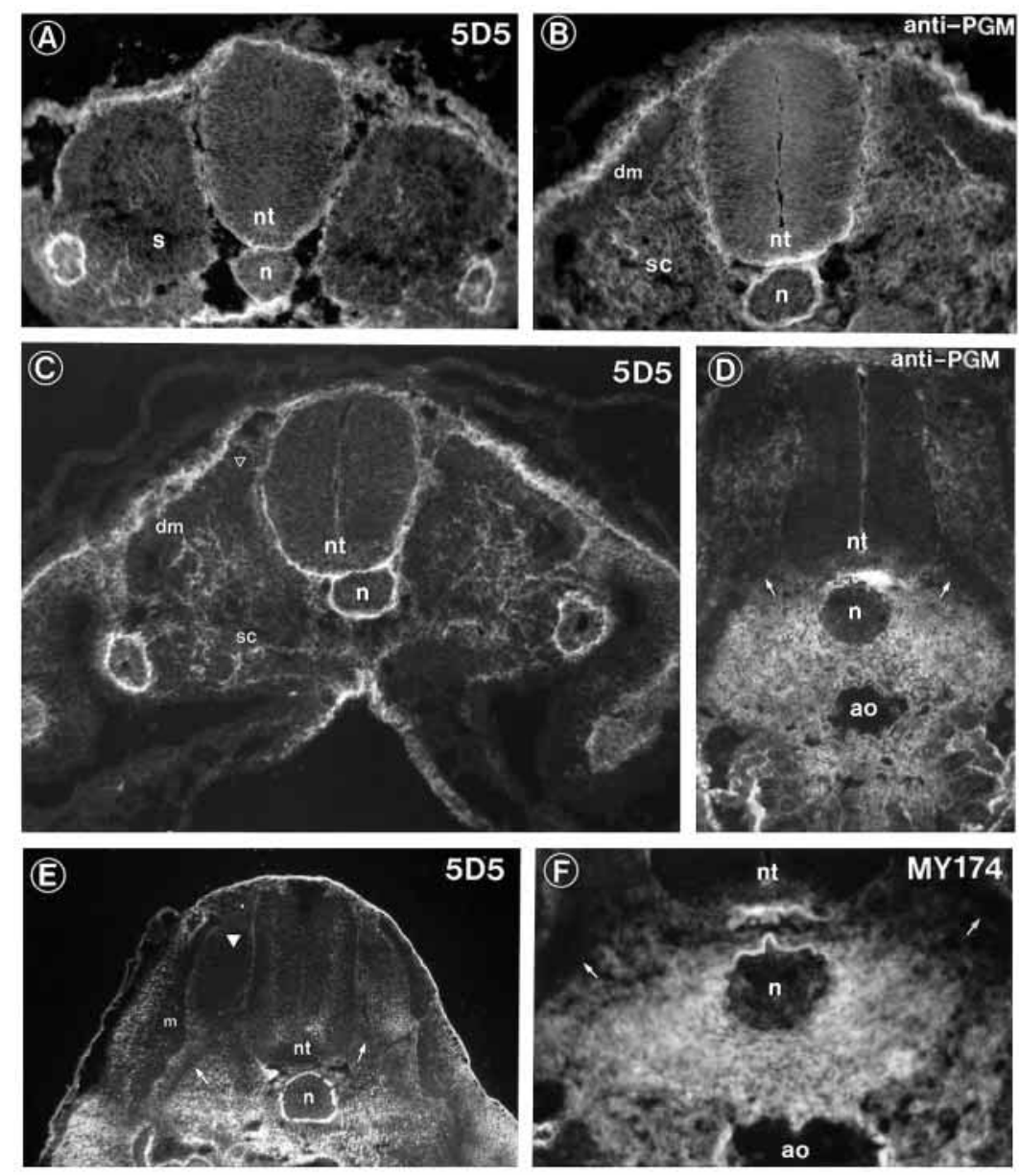

Fig. 3. Representative immunohistochemical stainings observed with the anti-PG$\mathrm{M} /$ versican antibodies indicated on each micrograph. Developmental stages and axial levels were as follows: (A) stage 16 midtrunk; (B) stage 17 midtrunk; (C) stage 18 limb bud region; (D) stage 23 wing bud region; (E) stage 22 midtrunk; and (F) stage 23 wing bud region. Both the ventral motor axons covered by the presumptive NC-derived Schwann cells (arrows) and the dorsal sensory ganglia (arrowhead) were consistently devoid of PG-M/versicans. Note also the denser distribution PG-M/versicans in the ventral regions of the embryo, when compared to the more dorsal ones, both during the course of NC cell movement and following the formation of the peripheral nervous ganglia. Abbreviations: nt, neural tube; n, notochord; s, somite; dm, dermomyotome; sc, sclerotome; $\mathrm{m}$, myotome; ao, aorta. Magnifications: A, ×230; B, ×350; C, ×120; D, ×410; E, $\times 130 ; \mathrm{F}, \times 440$. 
Fig. 4. Immunohistochemical distribution of PG$\mathrm{M} /$ versican core proteins in relation to their chondroitin sulfate moieties, aggrecan core protein and migrating NC cells detected by the HNK-1 antibody. Antibodies used in the single and doublelabelling experiments are indicated. (A) Longitudinal section through the midtrunk portion of a stage 17 embryo showing the distribution of migrating NC cells in relation to the total bulk of immunolocalized PG-M/versicans. Cells migrate through the rostral $(r)$ portion of the sclerotome (light red), while the proteoglycans progressively reorganize to the caudal (c) portion (light green), following an anterior-toposterior $(a \leftrightarrow p)$ sequence, which accompanies cell compaction of the cells to form the dorsal sensory ganglia. $(B, C)$ The same sagittal section through the midtrunk portion of a stage 18 embryo, in which a segment of the premigratory NC was surgically removed. PG-M/versicans become progressively excluded from the area occupied by the advancing NC cells. (D,E) Transverse sections through the midtrunk regions of embryos at stages 23 (D) and 18 (E) showing the perinotochordal extension of aggrecans (red) (comprising both molecules substituted with oligosaccharides embodying the HNK-1 epitope and molecules lacking such moieties) in relation to: the extending ventral motor axons (empty arrowheads),
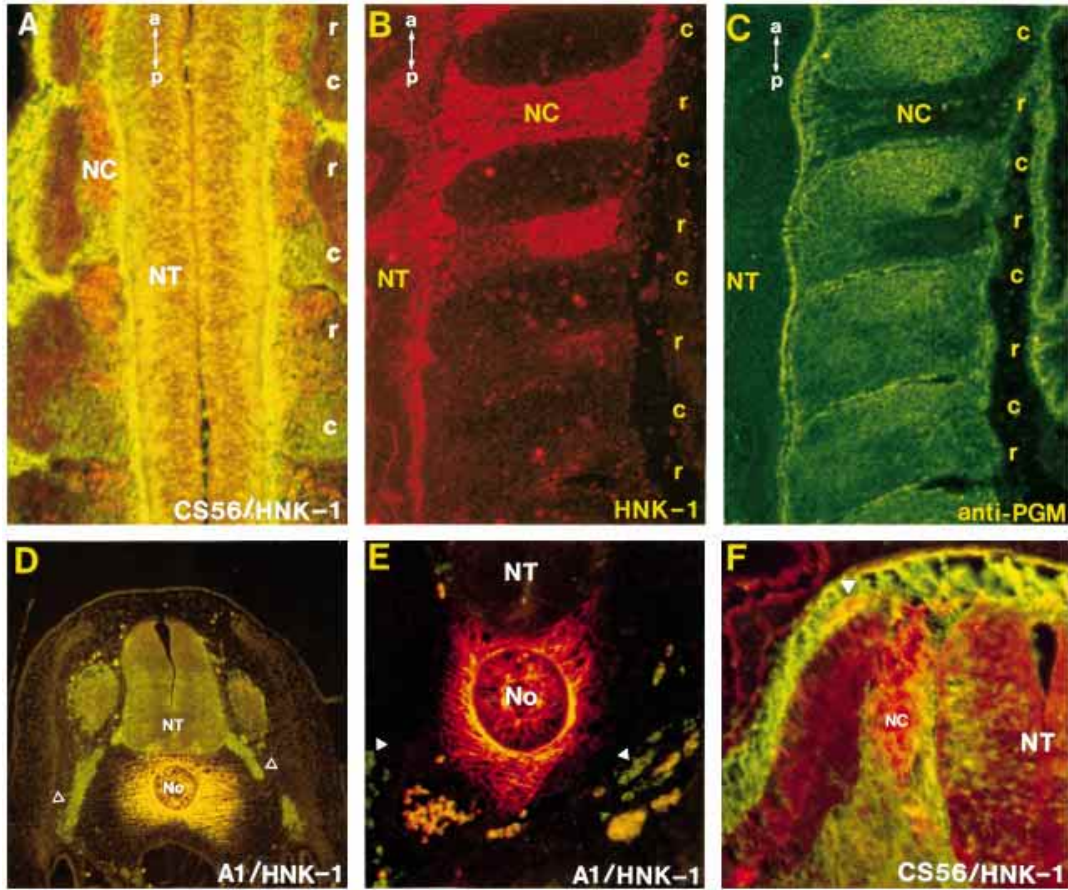

including the prospective NC-derived Schwann cells and individual NC cells (filled arrowhead) migrating in the subaortic region (all green). (F) Single NC cells (light red) migrating along the dorsolateral subectodermal pathway, which is entirely enmeshed in an ECM rich in PG$\mathrm{M} /$ versicans (green).

showed a more restricted distribution (not shown). Aggrecan was confined to the prechondrogenic region, where it demarcated a nonpermissive area for the extending ventral motor axonal bundles ensheathed by NC-derived Schwann cell precursors (Fig. 3D). During the course of NC cell movement and peripheral gangliogenesis/chondrogenesis, we (on the protein level) and others (on the mRNA level; Bundy et al., 1998) have noticed that the aggrecan distribution in the prechondrogenic mesenchyme becomes progressively metameric emanating dorsolaterally and ventrally from the perinotochordal regions at axial levels intermediary to those occupied by the ganglia. Eventually, the aggrecan-containing ECM entirely encapsulates the neural tube at axial levels between the ganglia and delineating the prechondrogenic tissue in the process of forming the presumptive vertebrate column (Fig. 5). Interestingly, in contrast to the perinotochordal aggrecan, the core protein of this 'perineural aggrecan' does not seem to carry either keratan sulfates or the HNK-1 antigen and is therefore reminiscent of that proposed to be expressed around the early notochord (Domowicz et al., 1995). Furthermore, the staining pattern obtained here with mAbs

Fig. 5. Immunolocalization of aggrecan core protein at stages following gangliogenesis and concurrent with chondrogenesis, viewed in sequential sections through the midtrunk region of a stage 24 chick embryo. Note the condensation of the perinotochordal cells in process of differentiating into chondrocytes and the aggrecanpositive subchordal structure eventually giving rise to the dorsal spines of the vertebral column. At these stages, the dorsal peri-neural tube extension of aggrecan is still alternating in a metameric fashion the distribution of the sensory ganglia: $(\mathrm{A}, \mathrm{B})$ correspond to a ganglionic axial level, (C,D) correspond to an intermediary axial level.
4C5 and 4G2, and the previously observed stainings with mAb 4D3 (Perris et al., 1991a), indicate that PG-M/versicans deposited in the perinotochordal region and along the ventrolateral neural tube surface may preferentially bear dermatan sulfate/chondroitin-4-sulfate chains.
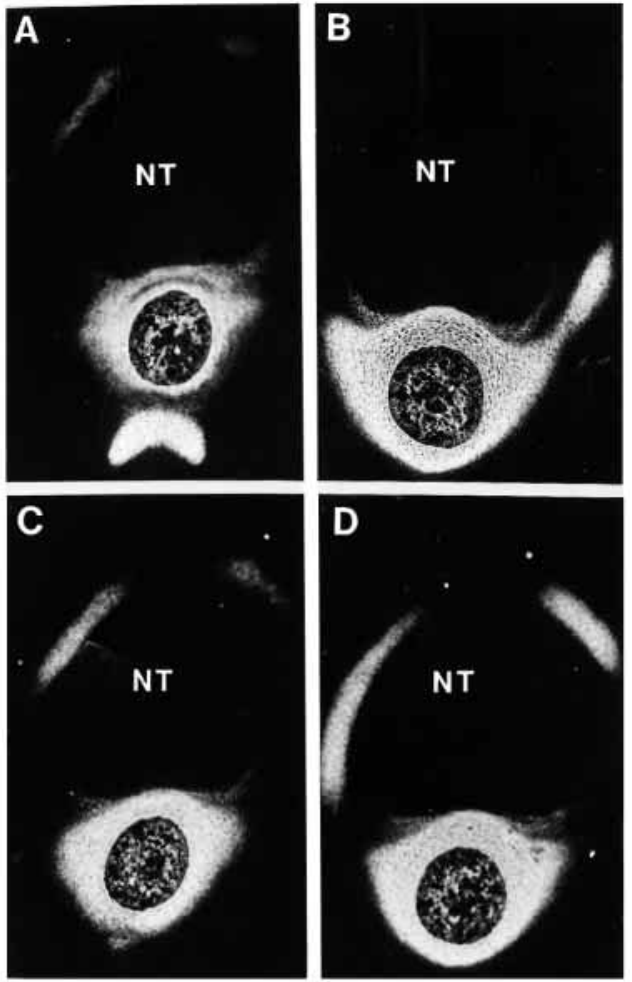
Fig. 6. Analytical and preparative chromatographic separation of PG-M/versicans expressed the during the course of NC cell migration and gangliogenesis. (A) Analytical separation of PG-M/versicans expressed in the trunk region at initial phases of $\mathrm{NC}$ cell migration (stage 15; St 15), advanced migration (stage 17; St 17) and following gangliogenesis (stage 23; St 23), and their identification by immunoassays using mAbs MY174, 5D5 and CS56. Graphs show the elution profiles of gel permeation chromatographs on CL-2B Sepharose obtained by ELISA on the eluted fractions with the indicated antibodies. S/Ab refer to silver/Alcian bluestained proteoglycans, which were pooled and ethanol precipitated from fractions 17-34, and resolved by SDSagarose gel electrophoresis. At any given stage, the major bulk of PG-M/versicans eluted immediately after the void volume of the column $\left(\mathrm{V}_{0}\right)$, whereas some chondroitin sulfate-free material reactive with both mAbs 5D5 and MY174 eluted with the total volume of the column $\left(\mathrm{V}_{\text {tot }}\right)$. (B) Purification of PG-M/versicans expressed along the NC migratory routes at advanced stages of movement (stage 17) by ion-exchange chromatographs on DEAE Sepharose (left panel) and Mono-Q columns (right panel) eluted with linear gradients of $\mathrm{NaCl}$ or $\mathrm{LiClO}_{4}$. Elution from DEAE Sepharose columns was monitored by ELISA and immunoblotting using mAb 5D5, whereas Mono-Q chromatographs were monitored by adsorbance readings
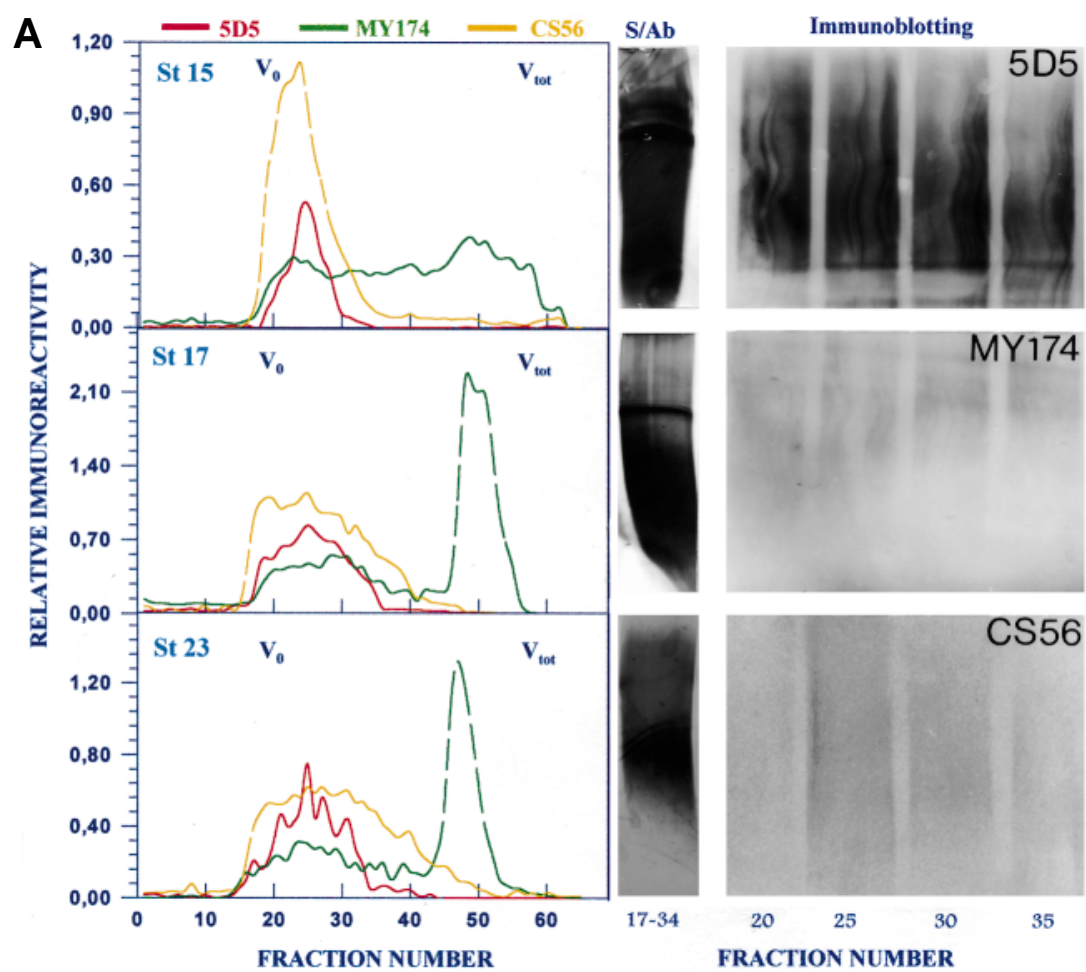

at 214 and $280 \mathrm{~nm}$. In both chromatographic separations, two major peaks were detected, which are indicated by dark-red and dark-blue arrows, respectively. Due to the minute amounts of proteoglycan contained by the second peak (dark-blue arrow), the content of this latter peak was not further investigated. The material contained by the peak indicated by the dark-red arrow was further analyzed by immunoblotting with and without prior chondroitinase ABC (Chase) and endo- $\beta$-galactosidase (Endo $\beta$ gal) digestion and using the indicated antibodies. Position of the molecular weight standards, including the $\alpha 1$ chain of EHS laminin-1 (400 kDa), an IgM-class immunoglobulin (950 kDa), thyroglobulin (669 $\mathrm{kDa})$, ferritin $(440 \mathrm{kDa})$, catalase $(232 \mathrm{kDa})$, myosin II $(205 \mathrm{kDa})$, $\beta$-galactosidase $(116 \mathrm{kDa})$ and phosphorylase $(97 \mathrm{kDa})$ is indicated for the different immunoblots.

\section{Isolation and biochemical/immunochemical characterization of PG-M/versicans}

Analytical gel permeation chromatography showed that large $M_{r}$ chondroitin sulfate-bearing proteoglycans recognized by antiPG-M/versican antibodies had a $K_{a v}$ of 0.26 (Fig. 6A). These proteoglycans were not reactive with the anti-aggrecan antiserum A1 (not shown) and were predominantly substituted with chondroitin-6-sulfates, as judged by the coincident reactivity with anti-chondroitin sulfate mAb CS56 (Fig. 6A) and the chondroitin-6-sulfate-specific mAb 3B3 (Perris et al., 1991a), and the poor-to-absent immunoreactivity with mAbs 1B5 (unsulfated chondroitin), 2B6 (chondroitin-4-sulfate/dermatan sulfate), 10E4 (anti-heparan sulfate), 5D4, 4D1, 2B3 and 3B2 (keratan sulfate; not shown). Both silver/Alcian blue staining and immunoblotting of the proteoglycans resolved by SDS-agarose gel electrophoresis indicated a high degree of polydispersity, which greatly surpassed that observed for PG-M/versicans from adult mammalian tissues (Schmalfeldt et al., 1998; M. Schiappacassi, D. P., S. Cattaruzza, P. Spessotto, A. C. and R. P., unpublished data).

Some material reactive with mAb MY174 eluted with apparent lower hydrodynamic sizes (especially when deriving from more advanced stages of development; Fig. 6A). The nature of this MY174-reactive proteoglycan was not examined, but it may correspond to naturally occurring degradation products of PG-M/versicans similar to those found in the adult human brain (Perides et al., 1996). The possibility also remains that the MY174-immunoreactive material may represent additional uncharacterized splice variants of the PG$\mathrm{M} /$ versican, which, similarly to the V3 isoform, may lack glycosaminoglycan chains.

Several rounds of ion-exchange chromatography were needed to separate PG-M/versicans. In the first one, they were retrieved in a sequential manner after $\mathrm{NaCl}$ elution, starting at $0.41 \mathrm{M}$ and ending at $1.2 \mathrm{M}$ (Fig. 6B). A second ion-exchange chromatography by HPLC on Mono-Q columns, eluted with a linear $\mathrm{LiOCl}_{4}$ gradient, yielded a comparable but sharper chromatographic profile. The first peak eluting at $0.22 \mathrm{M}$ showed the highest protein content (Fig. 6B), as confirmed by comparative adsorbance readings at 214, 260 and $280 \mathrm{~nm}$ (not shown). PG-M/versicancontaining fractions were analyzed by immunoblotting with and without prior enzymatic digestion with heparitinase III (not shown), chondroitinase $\mathrm{ABC}$ and endo- $\beta$-galactosidase (Fig. 6B). Endo- $\beta$-galactosidase digestion did not alter the electrophoretic mobility of the proteoglycans and similar results were obtained after digestion with either keratanase I or keratanase II (not shown). Comparisons of the relative electrophoretic mobilities of an unreduced IgM ( $900 \mathrm{kDa})$ molecule, intact EHS laminin-1 (approx. 1,000 kDa) and intact tetramers of collagen type VI $(\sim 2,400 \mathrm{kDa})$, showed that the molecular sizes of the isolated PG-M/versicans fell within an apparent $M_{r}$ range of 1,200-2,000,000.

Upon chondroitinase $\mathrm{ABC}$ digestion, a series of $\geq 7$ discernible bands, with the slowest migrating and most intense 
B

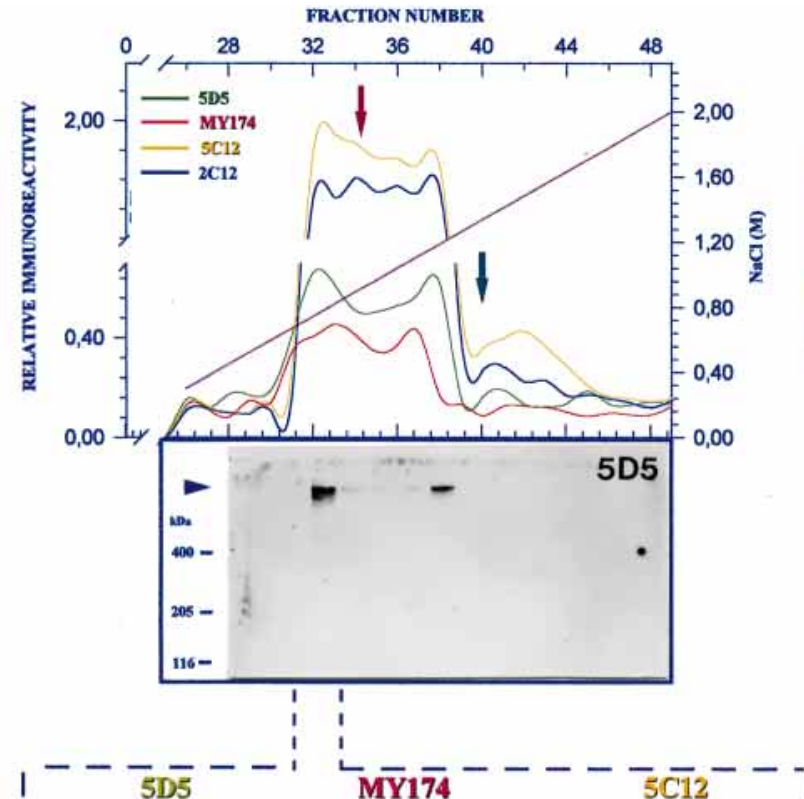

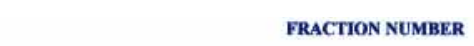
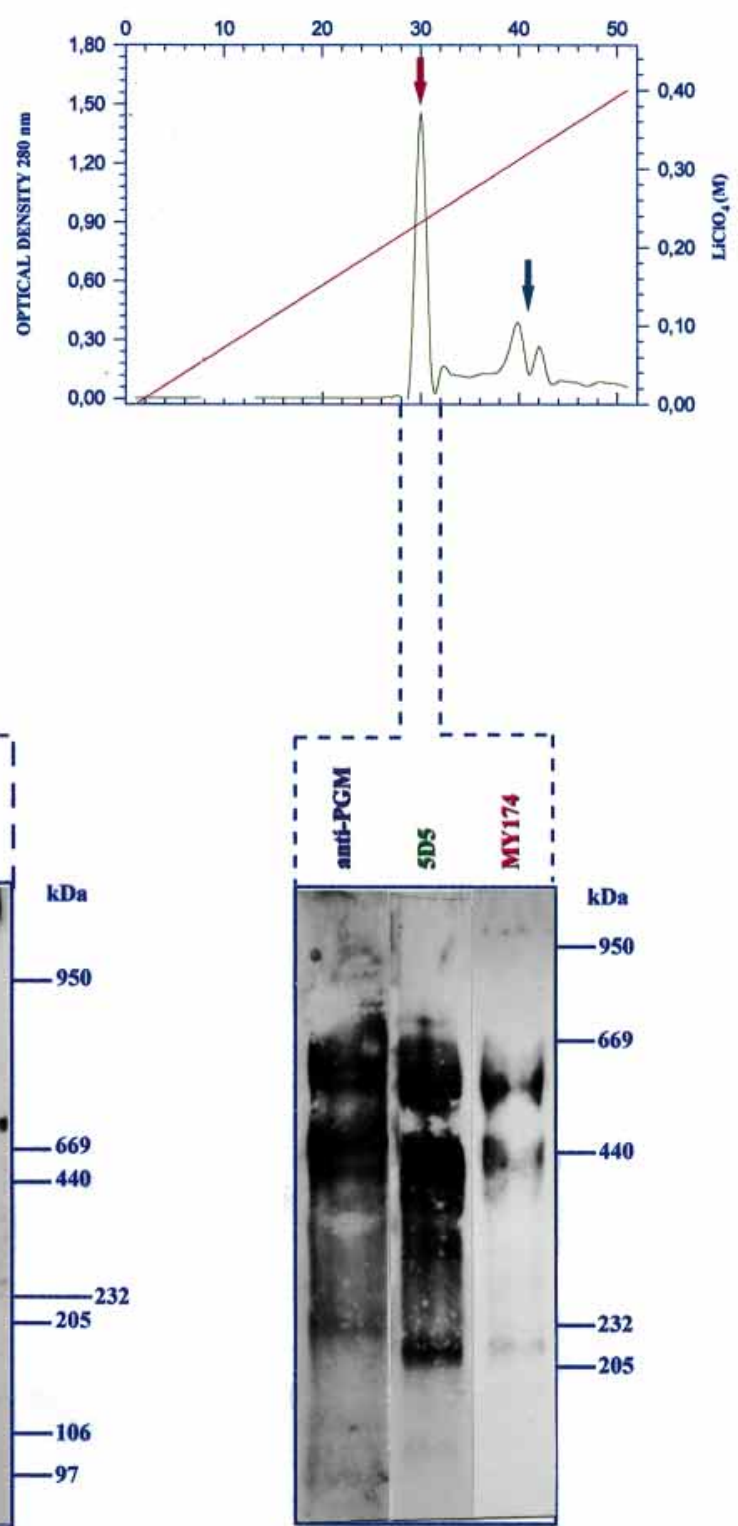

bands recognized by mAbs 5D5 and MY174 and the anti-PG$\mathrm{M}$ antiserum resolving at $490-510 \mathrm{kDa}$ and at $490-530 \mathrm{kDa}$, and the fastest migrating one recognized primarily by $\mathrm{mAb}$ 5D5 resolving at $215-225 \mathrm{kDa}$ (Fig. 6B). Intermediate immunoreactive bands ran at 390, 350, 280 and $245 \mathrm{kDa}$. The material obtained after elution of Mono-Q columns with $\mathrm{LiOCl}_{4}$ exhibited partly overlapping traits with two major, heavily glycosylated PG-M/versican core protein populations migrating at 490 and $360 \mathrm{kDa}$, followed by two bands at 280 and 215-220 $\mathrm{kDa}$, which were intensely stained by mAb 5D5, but only weakly labelled by the anti-PG-M antiserum and mAb MY174 (Fig. 6B). These lower $M_{r}$ bands are presumed to correspond to degradation products. Moreover, in this material, the 390 and $245 \mathrm{kDa}$ bands were less abundant than after ion-exchange chromatography combined with $\mathrm{NaCl}$ elution. Conclusively, the immunoblotting banding pattern observed for early embryonic PG-M/versicans purified according to the herein adopted purification procedures was concordant with that previously reported after immunoblotting of whole tissue extracts with mAb MY174 and of late embryonic PG-M/versicans V0 and V1 of various tissue origins (Yamagata et al., 1993).

\section{Ultrastructural traits of PG-M/versicans}

When examined by TEM involving rotary shadowing, PG$\mathrm{M} /$ versicans purified from the trunk region of embryos at stages of advanced NC cell migration exhibited the characteristic bi-globular appearance and seemed to carry relatively few extended side chains (Fig. 7A,C). The ultrastructural appearance of these molecules was compared to that of the previously described for bovine aorta PG-M/versican V1/V2 isoforms (Mörgelin et al., 1989). Comparative length measurements of the stretched proteoglycan molecules showed a relative size distribution of the isolated core proteins that was consistent with the expected lengths for V0 and V1 isoforms (Fig. 7B,D). Moreover, the size distribution observed in proteoglycans isolated from the $\mathrm{NC}$ migratory pathways 
Fig. 7. Ultrastructural analysis of PG-M/versicans extracted from embryonic trunks of stage 17 chick embryos (A,E,F) and from adult bovine aorta (C). Arrows point to the predominant molecular species, based on core protein length measurements. Arrowhead in A points to a putative $\mathrm{PG}-\mathrm{M} /$ versican $\mathrm{V} 1$ isoform shown at high power in F. Arrowheads in E point to the globular domain of a PG-

$\mathrm{M} /$ versican V0 isoform. (F) Close up of the putative V1 isoform showing the relatively few and extended glycosaminoglycan chains (arrow) attached to this isoform. (B,D) Graphic representations of the relative frequencies of the differently sized PG-M/versicans in each preparation (based upon the lengths measured for their core proteins).
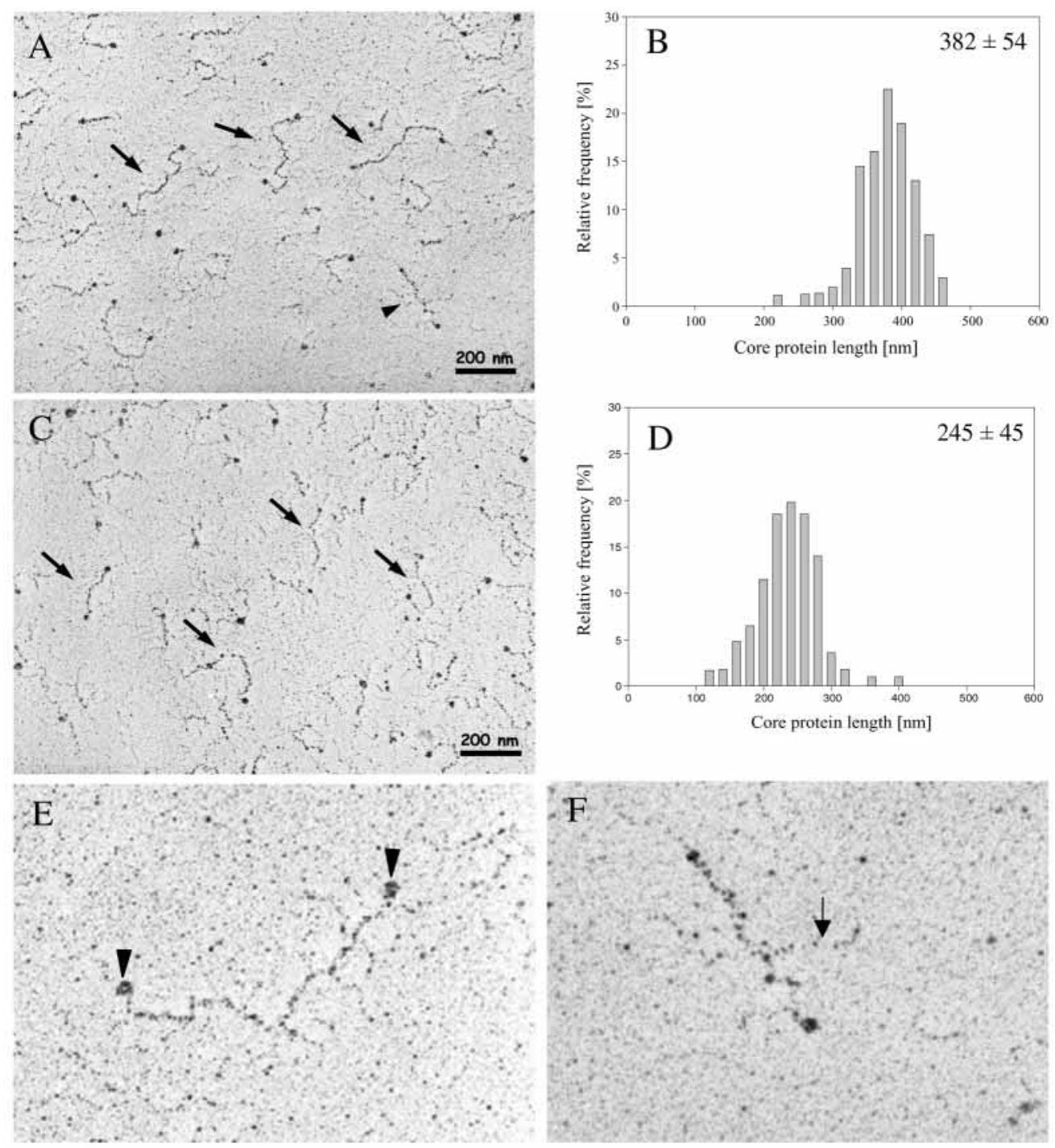

indicates a more homogeneous population of molecules and was compatible with the mRNA expression data showing a prevalence of the PG-M/versican V0 isoform. Accordingly, a significantly greater number of embryonic trunk proteoglycan molecules had an approximate length of $400 \mathrm{~nm}$ (Fig. 7B,E), whereas the less represented putative V1 isoform was 50-100 $\mathrm{nm}$ shorter (Fig. 7B,F). Differences in apparent molecular homogeneity in the avian embryonic and bovine adult preparations could indicate that embryonic trunk PG$\mathrm{M} /$ versicans are more homogeneously glycanated, such as to render the core proteins more uniformly stretchable during sample preparation. Interestingly, although the putative embryonic V1 isoform only differs from the V0 isoform in the lack of a relatively short glycosaminoglycan-binding domain, it seemed to carry significantly fewer and more elongated chains than those present on the V0 isoform (Fig. 7E,F).

\section{'Redirection' of NC cell migration in vivo by orthotopical implantation of PG-M/versicans bound to micromembranes}

To compare the effects of PG-M/versicans and aggrecans on $\mathrm{NC}$ cell migration in vivo, purified proteoglycans were immobilized onto micromembranes and implanted into the migratory pathways of the NC prior to the onset of migration. This type of implantation created two distinct experimental situations: (1) the orthotopic implantation of purified PG$\mathrm{M} /$ versican isoform $\mathrm{V} 0$, a mixture of $\mathrm{V} 0 / \mathrm{V} 1$, or a mixture of $\mathrm{V} 1 / \mathrm{V} 2$, resulted in dispersing cells being confronted with a locally enhanced concentration of either of these PG$\mathrm{M} /$ versican isoforms/isoform combinations, and (2) ectopic implantations of a notochordal-like aggrecan caused migrating cells to be confronted with the heterotopically localized proteoglycan.

When either proteoglycan- or fibronectin-coated micromembranes (the latter ones used as reference due to the well-established motility-promoting activity of fibronectin in vitro and in vivo) were implanted into regions lacking active $\mathrm{NC}$ cell migration, they did not exert any overt effect on the pattern of NC cell migration (not shown). In fact, micromembranes inserted into either the most ventrolateral region of the sclerotome (at level with the pronephric ducts), or adjacent to the notochord, neither attracted cells into those areas nor caused any other abnormalities in the migration of the cells. This indicated that implantation of micromembranes 
Table 2. Effects of topical implantation of proteoglycans on NC cell migration

\begin{tabular}{|c|c|c|c|c|c|c|}
\hline \multirow[b]{2}{*}{ Implanted molecule ${ }^{1}$} & \multirow{2}{*}{$\begin{array}{c}\text { Total } \\
\text { number of } \\
\text { embryos }^{2}\end{array}$} & \multirow{2}{*}{$\begin{array}{c}\text { Total } \% \text { of } \\
\text { embryos showing } \\
\text { affected NC cell } \\
\text { migration }{ }^{3}\end{array}$} & \multicolumn{4}{|c|}{$\begin{array}{l}\text { Percentage of embryos showing affected NC cell migration } \\
\text { according to the final localization of implant }(n=\text { total })^{4}\end{array}$} \\
\hline & & & $\begin{array}{c}\text { Dorsal } \\
\text { sclerotome }(\mathrm{A})\end{array}$ & $\begin{array}{l}\text { Subectodermal } \\
\text { space }(\mathbf{J})\end{array}$ & $\begin{array}{l}\text { Dermomyotome } \\
\text { (G) }\end{array}$ & $\begin{array}{c}\text { Ventral } \\
\text { sclerotome (D) }\end{array}$ \\
\hline None & 14 & 14 & $0(7)$ & $0(1)$ & $0(3)$ & $0(3)$ \\
\hline PG-M-V0 & 19 & 79 & $42(8)$ & $100(2)$ & $100(3)$ & $11(6)$ \\
\hline PG-M-V0/V1 & 3 & 67 & $100(1)$ & - & - & $50(2)$ \\
\hline PG-M-V1/V2 & 9 & 67 & $80(5)$ & - & $50(2)$ & $50(2)$ \\
\hline CNLA & 28 & 78 & $91(11)$ & $100(3)$ & $66(6)$ & $89(9)$ \\
\hline CNLA-Chase & 17 & 47 & $54(13)$ & $0(0)$ & $50(2)$ & $50(2)$ \\
\hline CNLA-Chase+E $\beta g$ & 16 & 17 & $18(11)$ & $0(0)$ & $0(2)$ & $34(3)$ \\
\hline HA-aggrecan & 11 & 45 & $67(6)$ & $0(0)$ & $0(1)$ & $34(3)$ \\
\hline Fibronectin & 17 & 29 & $12(8)$ & $0(2)$ & $0(3)$ & $18(4)$ \\
\hline
\end{tabular}

${ }^{1}$ Purified ECM molecules immobilized onto micromembranes and implanted into various regions of the living embryo were: PG-M/V0, PG-M/versican isoform V0 from cultured chick fibroblasts; PG-M-V0/V1, PG-M/versican isoforms isolated from NC migratory pathways; PG-M-V1/V2, PG-M/versican isoforms V1/V2 from bovine aorta; CNLA, chick notochordal-like aggrecan; CNLA-Chase, chondroitinase ABC-digested aggrecan; CNLA-Chase+E $\beta$, chondroitinase $\mathrm{ABC}$ and endo- $\beta$-galactosidase-digested aggrecan; HA-aggrecan, native multimeric hyaluronan-aggrecan complexes from bovine nasal cartilage

${ }^{2}$ Each embryo received a unilateral implant

${ }^{3}$ Refers to both impaired progression of NC cells along the normal migratory pathways upon contact with the proteoglycan implant and "redirected" NC cell movement towards the implant

${ }^{4}$ Embryos showing affected NC cell migration had either cells in close apposition (and mostly clustered) to the implanted micromembranes (aggrecan) or

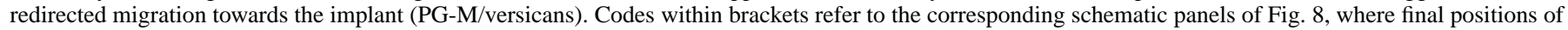
the implants are defined as follows: (A) dorsal sclerotome; (J) apical subectodermal space; (G) medial sclerotome/mid-dermomyotome; and (D) ventral sclerotome.

per se did not elicit secondary effects on cell movement. Similarly, uncoated micromembranes and fibronectin-coated micromembranes that were implanted into areas invaded by the dispersing NC cells did not significantly affect their migratory behaviour and, hence, cells advanced over both sides of the membranes (Fig. 8A,B; Table 2). However, in about $30 \%$ of the fibronectin implants, cells tended to deviate from their normal trajectory and move toward the implants (Table 2).

Micromembranes coated with the avian fibroblast PG$\mathrm{M} /$ versican V0, the embryonic trunk V0/V1 or the bovine aorta V1/V2 isoforms had variable effects depending upon: the isoform combination, the location of the implant, and the developmental stage at which the effect of the implant was evaluated. Thus, if the proteoglycan implants localized within the NC migratory pathways (Fig. 8A), there was a 'directed' migration towards the implants in $>50 \%$ of the cases. The degree of deviation seemed to be determined by whether the implant was localized within the dermomyotome or in the dorsal sclerotome (Table 2), whereas, if positioned within the subectodermal space, there were simply more cells entering this space than in the contralateral side. In contrast, if the PG-M/versican-coated micromembranes localized within the medioventral sclerotome/middermomyotome, the apparently 'redirected' NC cell migration towards the implanted membrane was observed in $>70 \%$ of the cases (Fig. 8D,E; Table 2). The deviation from the normal migratory trajectory in response to the proteoglycan implants was most pronounced for ventral motor axons and NC-derived Schwann cell progenitors (Fig. $8 \mathrm{~F})$. In contrast, when implants were localized in the endogeneously PG-M/versican-rich ventral portion of the sclerotome, migrating $\mathrm{NC}$ cells encountering them tended to circumvent the implants, even when these were oriented perpendicularly to the migratory trajectory of the cells (Fig. 9A,B). Thus, in these cases, it seemed that the local environment was more 'attractive' than that provide by the PG-M/versican implant.

\section{Perturbation of NC cell migration in vivo by heterotopical implantation of micromembrane- bound aggrecans}

In contrast to the apparent 'attracting' effect of PG$\mathrm{M} /$ versicans, cell movement was consistently perturbed when aggrecan-coated micromembranes were implanted into the NC migratory pathways or within the medioventral sclerotome (Fig. 8A,D,G). Two types of alterations were then observed: (1) NC cells either associated with the surface of the micromembrane, often in smaller clusters, and exhibited an impaired ventral progression when compared to the controlateral reference side of the embryo, or (2) NC cells deviated spatiotemporally from their normal migratory trajectory by spreading over one or both surfaces of the implanted micromembrane. The most marked effect was observed when aggrecan-coated micromembranes were inserted into the dorsal portion of the sclerotome (Fig. 8C,H,I; Table 2), suggesting that early migrating cells were particularly susceptible to direct confrontation with the heterotopic implant. In this position, the micromembranes caused an apparent arrest of NC cell movement in $\sim 80 \%$ of the cases (Table 2).

$\mathrm{NC}$ cell movement was also blocked when aggrecan-coated micromembranes were introduced into the ventral portion of the sclerotome, resulting in $\mathrm{NC}$ cells being trapped close to the implant. Ultrastructural analysis of the cellmicromembrane interface showed that NC cells localizing in juxtaposition with the aggrecan-coated micromembrane established contacts with it focally through plasma membrane protrusions (Fig. 9E,F). However, the cells did not form typical electron-dense contacts, such as those previously observed in filopodia of migrating $\mathrm{NC}$ cells interacting with interstitial collagen fibrils (Perris et al., 1990). NC cells 

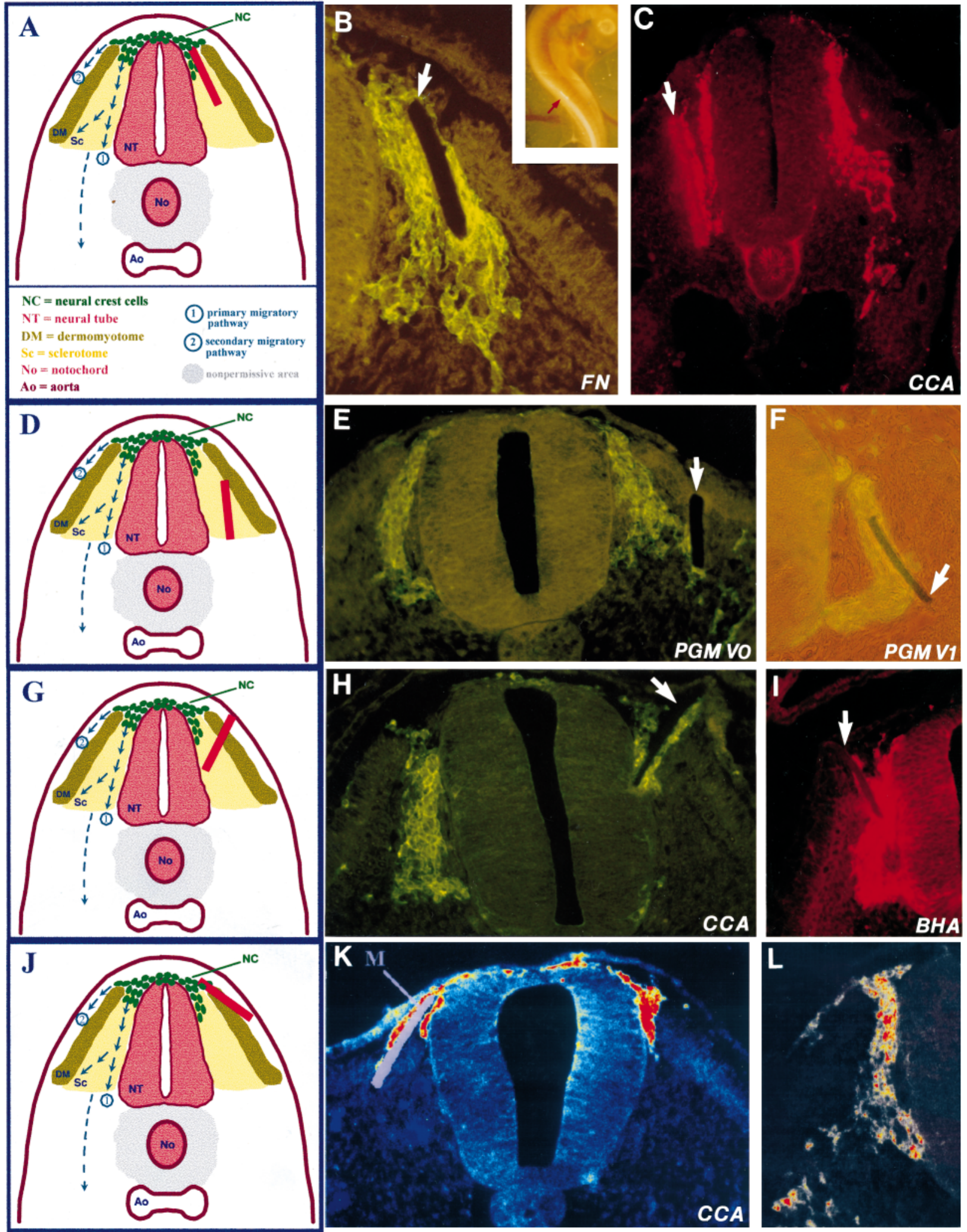

juxtaposed to aggrecan-coated micromembranes tended to cluster in about $60 \%$ of the cases examined. In contrast, control uncoated micromembranes and micromembranes coated with fibronectin, seldom had closely apposed cells (11\% and $23 \%$ of the cases, respectively, $n=14-17$ ) and did not cause cluster formation in association with the membrane surface $(0 \%$ and $6 \%$ of the cases, respectively).

Aggrecans and PG-M/versicans are assembled in the ECM in the form of oligomeric complexes arranged along a central hyaluronan filament and such native assemblies can be isolated 
Fig. 8. Effects of fibronectin- and proteoglycan-coated micromembrane implants on NC cell migration in vivo when evaluated by immunofluorescence and confocal laser microscopy of serial transverse sections from roughly comparable axial levels of stages 17-20 embryos. Migrating NC cells were evidenced by indirect immunohistochemical labellings with the HNK-1 antibody followed by detection with fluorescein- or Texas Red-conjugated secondary antibodies. Final positions of the micromembranes are indicated schematically for the most representative cases in the left panels $(A, D, G, J)$. These also indicate the two major NC migratory routes in the chick embryo (arbitrarily denoted primary and secondary migratory pathway, respectively). Molecules coated onto the micromembranes are indicated: FN, fibronectin; CCA, chick notochordal-like aggrecan; PGM V0, avian PG-M/versican V0; PGM V1, bovine aorta PG-M/versican V1/V2; BHA, link proteinstabilized hyaluronan-aggrecan complex from bovine nasal cartilage. Position of the micromembrane implants are indicated by the white arrows, except for inset in B in which the position of the implant is indicated by the red arrow. (K) The micromembrane (M) has been pseudocolored in violet. (F) Note how the extending ventral motor axons, which are encapsulated by the presumptive NC-derived Schwann cells, have been redirected towards the PG$\mathrm{M} /$ versican implant. Link protein-stabilized hyaluronan-aggrecan complexes also retained migrating $\mathrm{NC}$ cells in the vicinity of the membrane surface (I). Dorsolaterally migrating NC cells that encountered PG-M/versican and aggrecan-coated micromembrane progressed over the surface of the membrane as for analogous implants in other locations of the embryo. Developmental stages and axial levels are as follows: B, stage 17 lower trunk; C, stage 18 wing bud; E, stage 17 lower trunk; F, stage 20 midtrunk; stage 17 wing bud; I, stage 19 limb bud; K, stage 17 lower trunk; L, stage 17 midtrunk. In the pseudocolored confocal laser microscopy photographs in $\mathrm{K}$ and $\mathrm{L}$, red indicates the most intense fluorescence.

from bovine nasal cartilage and cultured rat chondrosarcoma cells (Mörgelin et al., 1989, 1992). We therefore implanted multimeric hyaluronan-aggrecan complexes bound onto micromembranes to determine whether the inhibitory effects of aggrecan would be exerted also in its naturally occurring macromolecular configuration. Intriguingly, these implants were substantially less effective in perturbing cell movement when compared to the monomeric aggrecan (Table 2). This discrepancy was not simply due to an intrinsic species-related difference in the monomeric bovine and rat aggrecan versus chick aggrecan, since, in their monomeric forms, these aggrecans caused similar effects to those seen with the chick aggrecan (data not shown). Aggrecan-coated micromembranes implanted into the subectodermal space (Fig. 8J) caused a similar effect to PG-M/versican implants into this region: NC cells remained associated with the membrane in a somewhat more advanced position in comparison to that of the contralateral side (Fig. 8K). However, NC cells retained on the surface of the subectodermally positioned proteoglycan-coated micromembrane were less advanced when compared to cells migrating along the same route at more anterior axial levels (Fig. 8L). This observation further confirms the generalized nonpermissive effect of aggrecan on NC cell migration. Furthermore, it is unlikely that the disparate effects seen for aggrecan and PG-M/versicans could be of a quantitative nature. This since lowering of the amount of proteoglycan coated onto membranes still caused the same type of effect, but with lower efficacy, similar results were also observed when using aggrecans from other tissue and species sources (data not shown),

The potential involvement of the chondroitin and keratan sulfate chains of the aggrecan in mediating its nonpermissive effects of NC cell migration has previously been proposed in vitro (Perris et al., 1996) and was explored here also in vivo by coating micromembranes with the chondroitinase $\mathrm{ABC}$, or combined chondroitinase $\mathrm{ABC} / \mathrm{endo}-\beta$-galactosidase, digested aggrecan. Both of these enzymatic treatments strongly reduced the ability of aggrecan to perturb NC cell migration with the strongest effect seen after removal of both types of glycosaminoglycan chains (Fig. 9C,D; Table 2). In these cases, dispersing cells that encountered the implanted modified proteoglycan failed to establish close contacts with it (Fig. 9D).

\section{Effects of PG-M/versican V0 and aggrecan on NC cell migration through three-dimensional Col I substrata}

NC cells migrate poorly through three-dimensional collagen substrata, but their movement can be enhanced by copolymerization of fibronectin (Perris et al., 1991b). This finding, as well as the inhibitory effect of the bovine nasal cartilage-derived aggrecan observed in previous experiments, were confirmed here using the chick notochordal-like aggrecan (Fig. 10). In contrast, copolymerization of the PG-M/versican V0 isoform created a Col I three-dimensional substratum that allowed for a significant movement of NC cells away from the neural tube explant and invasion of the polymer (Fig. 10). Movement of NC cells through the Col I-PG-M/versican V0 substratum was strictly dependent upon the concentration of the copolymerized proteoglycan, whereas the inverse relationship was observed at increasing concentrations of aggrecan (Fig. 10). NC cells were also confronted with polymeric Col I substrata in which the PG-M/versican V0 isoform was incorporated into the polymer at stepwise increasing or decreasing concentrations. In these cases, NC cell movement through Col I-PG-M/versican polymer was comparable to that observed with homogeneous concentrations of the proteoglycan and in Col I-fibronectin polymers (Fig. 10). In contrast, movement was markedly impeded when NC cells were confronted with a 'reverse gradient', i.e. the highest concentration first and progressively lower concentrations of the proteoglycan.

Addition of antibody HNK-1 did not significantly block the poor migration in the Col I polymer alone, or in the copolymerized Col I-fibronectin gel, but significantly inhibited NC cell movement through the Col I-PG-M/versican V0 substratum (Fig. 10). Antibodies MY174 and 5D5 binding close to the G1 globular domain (Table 1; M. Schiappacassi, D. P., S. Cattaruzza, P. Spessotto, A. C. and R. P., unpublished data) did not alter the migratory behaviour of the cells (data not shown). These preliminary observations are consistent with a NC-PG-M/versican interaction mediated by the C-terminal G3 globular domain (Perris et al., 1996). Video time-lapse recordings of these cell movements indicated a somewhat lower velocity for $\mathrm{NC}$ cell migrating through Col I-PG$\mathrm{M} /$ versican V0 when compared to Col I-fibronectin (43 $\mu \mathrm{m} /$ hour, $n=16$ versus $67 \mu \mathrm{m} /$ hour, $n=22)$, but an apparent higher degree of directional movement in the latter threedimensional substratum, which was not further quantified. Furthermore, as previously suggested (Perris, 1997), NC cell 
Fig. 9. (A-D) Migrating NC cells detected by the HNK-1 antibody in embryos that had received micromembrane implants (arrows) of intact and enzyme-digested proteoglycans in dorsal and ventral regions of the sclerotome. (A) Representative response of ventrally migrating NC cells to V1/V2 PG-M/versican isoforms from bovine aorta. In these cases, NC cells migrated both along the micromembrane surface as well as beyond it largely bypassing it. (B) A ventrally positioned PG$\mathrm{M} /$ versican V0 implant which, in that location, fails to 'attract' the extending ventral axon bundles and associated NC-derived Schwann cells. (C) Chondroitinase ABCtreated aggrecan (CCA-Chase) fails to entrap the majority of the ventrally migrating NC cells in it close proximity. (D) Migrating NC cells encountering a chondroitinase $\mathrm{ABC} /$ endo- $\beta$-galactosidase-digested aggrecan (CCA-C/E)carrying micromembrane entirely avoid the implant. (E,F) TEM micrographs portraying an overview (E) and an enlargement $(F)$ of the boxed area in sections taken from the ventral sclerotome of the midtrunk region of a stage 18 embryo in which an aggrecan (CCA)-coated micromembrane (M) had been implanted. Arrowheads point to the contact zones between the plasma membrane of migrating NC cells (nc) and the surface of the implant. White arrow points to the NC cell filopodium protruding over the surface of the aggrecan-coated micromembrane.
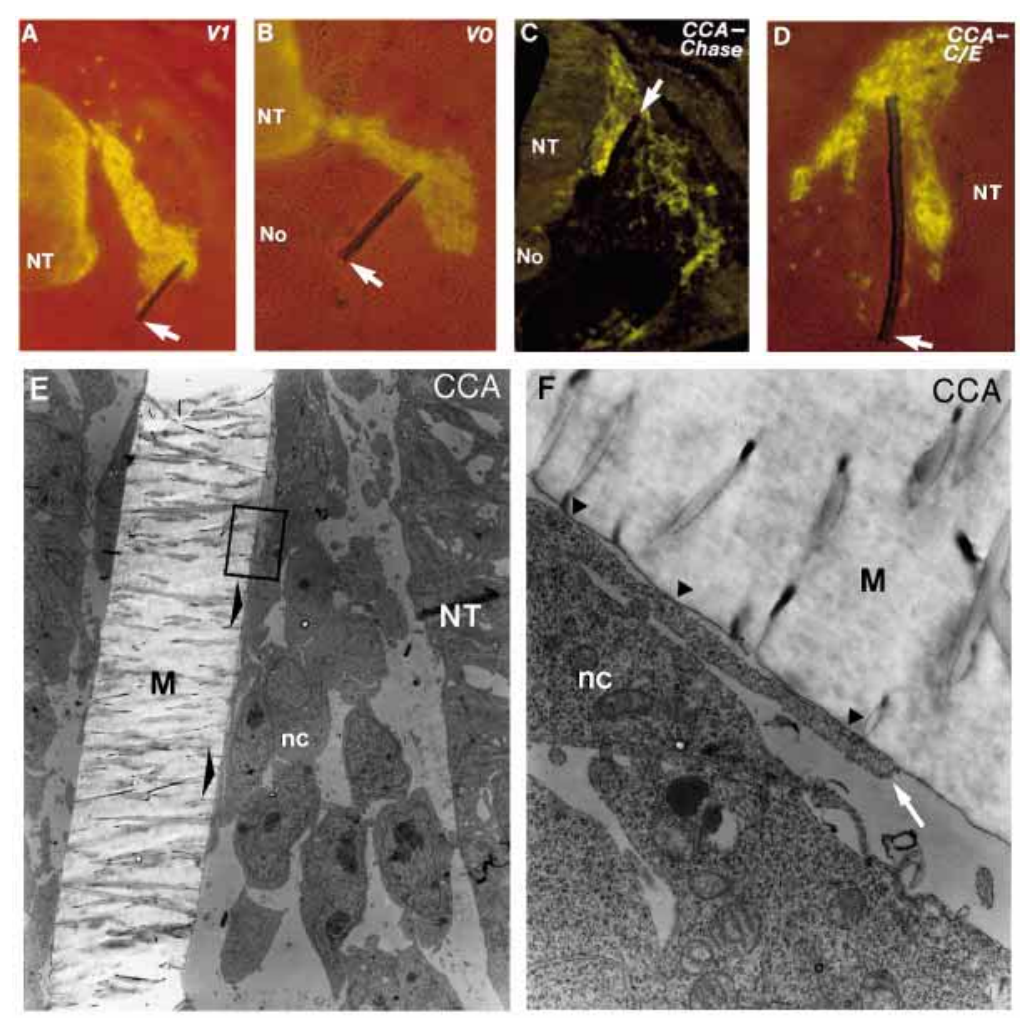

movement through these three-dimensional collagen substrata was dependent upon the activity of $\beta 1$ integrins (not shown).

\section{DISCUSSION}

The experiments in this study suggest that PG-M/versicans may not act as 'barrier molecules' exerting a repellent effect, but may rather function as pivotal cell-interactive elements of the interstitial ECM lining the NC migratory routes. In fact, PG-M/versicans were found to be widely expressed at both mRNA and protein level in tissues consituting the $\mathrm{NC}$ migratory pathways and to favor NC cell movement in vitro and in vivo.

The spatiotemporal distribution of $\mathrm{PG}-\mathrm{M} /$ versicans did not inversely correlate with the migratory tracks of $\mathrm{NC}$ cells. Conversely, laterally and medially migrating NC cells were found to be surrounded by a dense PG-M/versican ECM at all phases of migration and the tissue-specific reorganization of these proteoglycans seemed to be a direct consequence of $\mathrm{NC}$ morphogenesis. For instance, the transition from an initially

Fig. 10. Migration of NC cells through Col I three-dimensional substrata into which fibronectin (FN), the chick PG-M/versican V0 isoform or the chick notochordal aggrecan had been incorporated in different concentrations, either homogeneously distributed or in stepwise increased/decreased amounts (i.e. PG-

$\mathrm{M} /$ versican $^{10 / 50 / 100 / 500}$ and PG-M/versican $\left.{ }^{500 / 100 / 50 / 10}\right)$. NC cells were allowed to migrate through the polymers in the presence or absence of the HNK-1 antibody. Continuous and dashed lines correspond to $\mathrm{NC}$ cell migration into polymeric Col I substrata alone, or into Col I polymers containing $20 \mu \mathrm{g} / \mathrm{ml} \mathrm{FN}$, respectively. Data points represent means of 7-11 cultures per experimental situation. uniform to a preferentially caudal arrangement of sclerotomal PG-M/versicans is correlated with the progression of NC cell migration through the rostral portion and is firmly dependent upon this metameric migratory pattern. Thus, our findings support the previously reported segmental distribution of sclerotomal PG-M/versicans at advanced-to-final phases of NC cell migration (Tan et al., 1987; Landolt et al., 1995; Henderson et al., 1997), but reject the proposed occurrence of a premigratory, patterned $\mathrm{PG}-\mathrm{M} /$ versican distribution responsible for the segmental migration of $\mathrm{NC}$ cells along the body axis. On the contrary, distribution of aggrecan was found to be strictly confined to the migration-nonpermissive area around the notochord, to exhibit segmental variations in its dorsolateral extension as recently suggested by mRNA studies

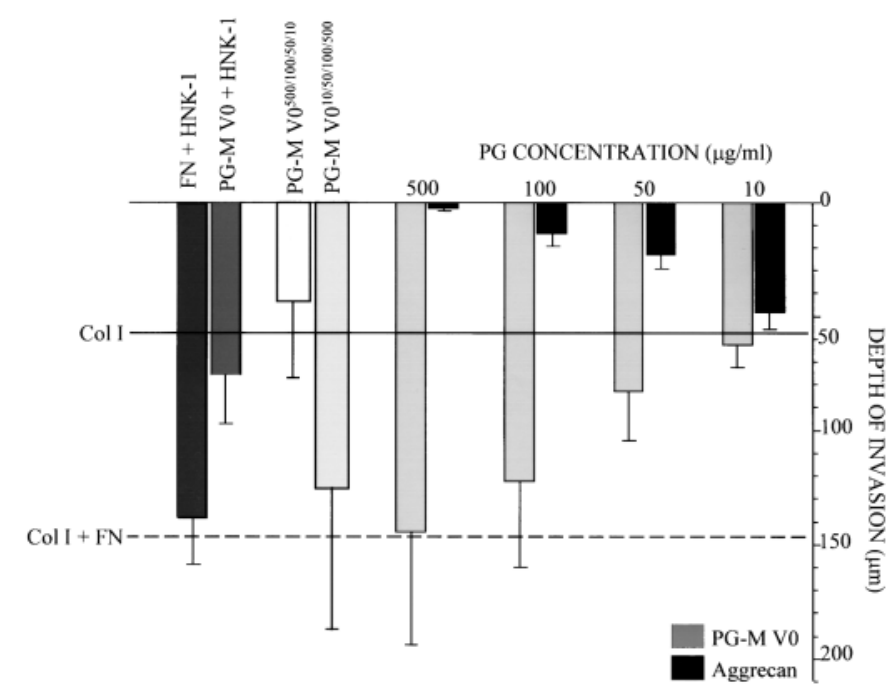


(Bundy et al., 1998), and to be remodelled by the migrating NC cells themselves. Finally, consistent with recent observations in the mouse embryo (Henderson et al., 1997), neither early migrating nor preganglionic NC cells express PG$\mathrm{M} /$ versican, whereas some $\mathrm{PG}-\mathrm{M} /$ versican expression could be detected within the aggregated ganglia and was assumed to be associated with supporting non-neuronal cells of these nervous structures.

V0 was the ubiquitously and most abundantly expressed PG-M/versican isoform during the course of $\mathrm{NC}$ cell movement, followed by $\mathrm{V} 1$; whereas $\mathrm{V} 2$ and V3 isoforms were substantially more weakly transcribed and/or virtually absent at these stages of development (we did not find evidence for the expression of other alternatively spliced forms). In adult mouse and human tissues, the V1 isoform is the prevailing isoform (Dours-Zimmermann et al., 1994; Shinomura et al., 1995; Yao et al., 1996; Zako et al., 1995; Ito et al., 1995; Schmalfeldt et al., 1998; M. Schiappacassi, D. P., S. Cattaruzza, P. Spessotto, A. C. and R. P., unpublished data) and this suggests that the inverse relationship in the embryonic versus adult splicing frequency of the V0 and V1 isoforms may represent a developmentally related transition in the RNA splicing control of this gene. Furthermore, since it has previously been suggested that the V2 isoform may be rather specific for the central nervous system (Schmalfeldt et al., 1998), the weak V2 mRNA expression detected by RTPCR in the developing chick trunk is likely to be restricted to the spinal cord. In situ hybridizations, which as for immunohistochemistry allow a distinction between the V0 and V1 or V0 and V2 distribution, indicated that PG$\mathrm{M} /$ versican transcription was more elevated in the ventral than dorsal regions of the embryo and was particularly concentrated in 'signalling zones' such as the floor platedorsal half of the notochord. Thus, the possibility remains that PG-M/versicans may be involved in some of the inductive events leading to neuronal specification within the spinal cord.

Chromatographic separation and partial biochemical/ immunochemical characterization of PG-M/versicans extracted from the $\mathrm{NC}$ migratory regions at distinct phases of $\mathrm{NC}$ development, in conjunction with previous and present immunochemistry on tissue sections, indicated that these proteoglycans were synthesized with a higher degree of chondroitin sulfate substitution at initial phases of NC cell migration than later on in development. Previous and current observations also indicated that the prevalent glycosaminoglycan chains of these early expressed PGM/versicans are of the chondroitin-6-sulfate/dermatan sulfate type, whereas, if present at all on a small number of early embryonic PG-M/versican molecules, unsulfated chondroitin, 4-sulfated chondroitin and keratan sulfates may be primarily restricted to the PG-M/versicans of the perinotochordal ECM. Overall, the chick PG-M/versicans described here closely resemble the homologous proteoglycans isolated from amphibian ectoderm (Stigson and Kjellén, 1991; Stigson et al., 1997a,b) and ventral trunk of quail embryos (Kerr and Newgreen, 1997; Dillon and R. Perris, unpublished data). Our immunohistochemical analyses further suggest that the PG$\mathrm{M} /$ versican V0/V1 isoforms deposited in the more ventral region of the embryo may preferentially carry dermatan sulfate chains, which similarly to keratan sulfates, are more likely to be the ones responsible for the 'repulsion-like' effects exerted on NC cell migration by the perinotochordal region.

The SDS-PAGE/immunoblotting banding pattern obtained after chondroitinase digestion for the core proteins of the isolated embryonic trunk PG-M/versicans was consistent with that previously observed for whole-tissue homogenates from late chick embryos (Yamagata et al., 1993) and isolated mammalian and late embryonic avian V0/V1 PG-M/versican isoforms (Habuchi et al., 1986; Kimata et al., 1986; Morita et al., 1990; Yamagata et al., 1993; Shinomura et al., 1993; Yao et al., 1996). Although SDS-PAGE bands at $\geq 500 \mathrm{kDa}$ have been proposed to correspond to the tissue form of PGM/versican V0 (Shinomura et al., 1993), data obtained here, as well as elsewhere for bovine and human PG-M/versicans (Mörgelin et al.,1989; Yao et al., 1996; M. Schiappacassi, D. P., S. Cattaruzza, P. Spessotto, A. C. and R. P., unpublished data), strongly favors the idea that the $400-500 \mathrm{kDa}$ bands may also encompass glycosylation variants of the V1 isoform. Ultrastructural analysis by TEM involving rotary shadowing ascertained the identity, purity and characteristic structural traits of the embryonic trunk PG-M/versicans, showing a prevalence of the V0 isoform and highlighting the possibility that the V1 isoform may carry longer and significantly fewer chondroitin sulfate chains. When compared with PG$\mathrm{M} /$ versicans isolated from adult bovine aortas, and predominantly encompassing the V2 isoform (Mörgelin et al., 1989; M. Schiappacassi, D. P., S. Cattaruzza, P. Spessotto, A. C. and R. P., unpublished data), PG-M/versicans from the early embryonic trunk seemed also more homogeneously glycanated.

We provide functional evidence that PG-M/versicans and aggrecan exert disparate and presumably opposed roles during $\mathrm{NC}$ cell movement in vivo. Heterotopic implantations of the purified proteoglycans into the migratory pathways of the NC demonstrates that PG-M/versicans of the ECM encountered by the moving cells may be conducive to migration, whereas the presence of aggrecan, which is the major constituent of the nonpermissive perinotochordal ECM (Pettway et al., 1990, 1996; Perris et al., 1996), inhibits NC cell movement. Nonetheless, local implantation of PG-M/versicans into the NC migratory pathways, or their adjacent embryonic regions, in most cases altered the spatial pattern of NC cell movement by 'redirecting' moving cells toward the implant. This effect appeared to be greater for the V1/V2 isoforms from bovine aorta and was most obvious following orthotopic PG$\mathrm{M} /$ versican implantations into the medioventral sclerotome, suggesting that the response of migrating NC cells to regional accumulations of $\mathrm{PG}-\mathrm{M} /$ versicans may be progressively modulated during their ventral progression through the embryo. On the basis of our present and previous distributional data (Perris et al., 1991a; Perris, 1997), we propose that the density of chondroitin sulfate-bearing proteoglycans increases in the developing embryo in a dorsal-to-ventral orientation.

Distribution and ECM arrangement of PG-M/versicans, as determined by in situ hybridization and immunohistochemistry, further suggest that the previously proposed accumulation of chondroitin sulfates in more ventral regions of the embryo may reflect an overabundance of proteoglycan molecules rather than an augmented glycanation level of equivalently densely distributed core proteins. Accordingly, NC cells progressing in the dorsal-to-ventral 
direction may move in a 'haptotactic-like' fashion toward embryonic regions with denser PG-M/versican concentrations (Perris, 1997). This idea is supported by two observations. First, implantation of micromembrane coated with PG$\mathrm{M} /$ versicans in the dorsal sclerotome caused NC cells to move toward the implant (more extensively than to fibronectin implants), whereas implants in the PG-M/versican-denser ventral portion of the sclerotome were ignored. Secondly, NC cells migrate through polymeric Col I substrata containing 'homogeneous' concentrations of PG-M/versicans, but not aggrecan, displaying a relatively high persistency in directionality and a similar locomotory efficiency as in the presence of fibronectin.

If NC cells were confronted with polymeric Col I substrata containing spatially increasing concentrations of PG$\mathrm{M} /$ versicans, they migrated extensively through the polymer, whereas a reversed concentration 'gradient' largely impeded the cells' invasion of the Col I-PG-M/versican polymer. Similar results have been obtained when $\mathrm{NC}$ cells have been confronted with increasing/decreasing concentrations of PG-M/versicans and fibronectin in Transwell assays (R. P., unpublished data). Finally, our in vitro data suggest that this apparently haptotactic migratory response of $\mathrm{NC}$ cells to PG-M/versicans is dependent upon the interaction of $\mathrm{HNK}-1$ epitope-bearing molecules of the NC cell surface with the C-terminal lectin C-type module of the G3 globular domain (Perris et al., 1996). If so, this finding would be consistent with recent observations showing that this module of hyalectan proteoglycans binds with high-affinity to sulfoglucuronylglycolipids characteristic of the HNK-1 epitope (Miura et al., 1999).

In contrast to PG-M/versicans, heterotopic implantation of aggrecan did not 'attract' cells toward the implant and did not allow their free migration through the pores of the aggrecancoated micromembrane, when positioned to form a physical obstacle for the ventral progression of the cells. However, when the micromembrane-bound aggrecan was inserted into the primary $\mathrm{NC}$ migratory pathway, NC cells remained in close contact with the implant. This tethering was accompanied by cell aggregation and may similarly have been contributed by the previously proposed (Perris et al., 1996) lectin-binding domain interaction with the NC cell surface HNK-1-reactive moieties. Thus, the behaviour exhibited by NC cells encountering ectopic aggrecan substrata in vivo was different from that observed in vitro, presumably due the conditioning by the natural tissue environment. The migration inhibitory effect was more pronounced for the monomeric avian aggrecan than for multimeric hyaluronan-aggrecan complexes from other tissue/species. This finding opens two possibilities: (1) the nonpermissive effect of the notochordal aggrecan is glycanation-dependent; and/or (2) the interaction of NC cellassociated hyaluronan with the G1 domain of aggrecan, which is tightly engaged in the stabilization of the hyaluronanaggrecan-link protein complexes, is too inefficient to liberate single aggrecan molecules for cell interaction. Accordingly, the apparent cell-surface-associated hyaluronan-mediated arrest of cultured NC cells in response to soluble aggrecans (Perris and Johansson, 1987, 1990; Perris et al., 1996; Kerr and Newgreen, 1997), and the inhibited NC cell migration in response to uncomplexed aggrecans in vivo, point to a dynamic aggrecan$\mathrm{NC}$ cell interplay that is modulated by the ECM assembly of this proteoglycan.
Micromembrane implants carrying aggrecan deprived of its glycosaminoglycan chains were less effective in perturbing NC cell movement. Our previous in vitro results indicated that, once aggrecans are allowed to freely interact with the NC cell surface, their keratan sulfate chains may play a central role in mediating their adverse effect on cell motility (Perris et al., 1996; Perris, 1997). Thus, while the function of PG$\mathrm{M} /$ versicans during NC development may be dictated by their core proteins, possibly through interactions with ECM (Tan et al., 1987; Aspberg et al., 1997, 1999) and cell surface ligands, the abundant and highly diversified glycan moieties of aggrecan are likely to be the ones primarily responsible for its inhibitory effects on cell movement. Conceivably, these inhibitory effects may be additionally operated through a side chain-mediated sequestration of motility-unfavorable soluble components. Blocking the interaction of PG-M/versicans with the cognate ECM and/or NC cell surface ligands in vitro and in vivo, e.g. via treatment with lectin-binding molecules (Krull et al., 1995), perturbs the pattern of NC cell migration. Thus, collectively, these previous findings, recent studies on mutant axolotl and mouse embryos, and our present data, suggest that precise qualitative and quantitative ECM arrangements of PG$\mathrm{M} /$ versicans are important in guiding NC cells to their ultimate sites. Other experiments confirm the unambiguous inhibitory effect of aggrecans on NC cell migration, and show the cardinal role of aggrecans in the structuring of the migrationnonpermissive perinotochordal area. Thus, two opposed roles are demonstrated for PG-M/versicans and aggrecans during avian NC development.

We thank Elena Gabriele, Michela Zanbon and Maria Teresa Mucignat for their technical assistance, Paola Spessotto for her assistance with the confocal laser microscopy, Gianluca Tell for performing HPLC chromatographies, and Guido David, Dick Heinegård, Firoz Rahemtulla and Michael Sorrell for their proteoglycan and antibody contribution. The work was supported by grants from Associazione Italiana della Ricerca sul Cancro (AIRC) and Fondo Sanitario Nazionale (FSN, RF-95 and RF-96).

\section{REFERENCES}

Aspberg, A., Adam, S., Kostka, G., Timpl, R. and Heinegård, D. (1999). Fibulin-1 is a ligand for the C-type lectin domains of aggrecan and versican. J. Biol. Chem. 274, 20444-20449.

Aspberg, A., Miura, R., Bourdoulous, S., Shimonaka, M., Heinegård, D., Schachner, M., Ruoslahti, E. and Yamaguchi, Y. (1997). The C-type lectin domains of lecticans, a family of aggregating chondroitin sulfate proteoglycans, bind tenascin-R by protein-protein interactions independent of carbohydrate moiety. Proc. Natl. Acad. Sci. USA 94, 10116-10121.

Bundy, J., Rogers, R., Hoffman, S. and Conway, S. J. (1998). Segmental expression of aggrecan in the non-segmented perinotochordal sheath underlies normal segmentation of the vertebral column. Mech. Dev. 79, 213 217.

Carrino, D. A., Dennis, J. E., Drushel, R. F., Haynesworth, S. E. and Caplan, A. I. (1994). Identity of the core protein of the large chondroitin sulfate proteoglycans synthesized by skeletal muscle and prechondrogenic mesenchyme. Biochem. J. 298, 51-60.

Domowicz, M. Li, H., Henning, A., Henry, J., Vertel, B. M. and Schwartz, N. B. (1995). The biochemically and immunologically distinct CSPG of notochord is a product of the aggrecan gene. Dev. Biol. 171, 655-664.

Dours-Zimmermann, M. T. and Zimmermann, D. R. (1994). A novel glycosaminoglycan attachment domain identified in two alternative splice variants of human versican. J. Biol. Chem. 269, 32992-32998.

Erickson, C. A. and Perris, R. (1993). The role of cell-cell and cell-matrix interactions in the morphogenesis of the neural crest. Dev. Biol. 159, 60-74. 
Habuchi, H., Kimata, K. and Susuki, S. (1986). Changes in proteoglycan composition during development of rat skin. The occurrence in fetal skin of a chondroitin sulfate proteoglycan with high turnover rate. J. Biol. Chem. 261, 1031-1040.

Henderson, D. J and Copp, A. J. (1997). Role of the extracellular matrix in neural crest cell migration. J. Anat. 191, 507-515.

Henderson, D. J. and Copp, A. J. (1998) Versican expression is associated with chamber specification, septation, and valvulogenesis in the developing mouse heart. Circ. Res. 83, 523-532.

Henderson, D. J., Ybot-Gonzalez, P. and Copp, A. J. (1997). Overexpression of the chondroitin sulphate proteoglycan versican is associated with defective neural crest migration in the Pax3 mutant mouse (splotch). Mech. Dev. 69, 39-51.

Ito, K., Shinomura, T., Zako, M., Uijta, M. and Kimata, K. (1995). Multiple forms of mouse PG-M, a large chondroitin sulfate proteoglycan generated by alternative splicing. J. Biol. Chem. 270, 958-965.

Kerr, R. S. E. and Newgreen, D. F. (1997). Isolation and characterization of chondroitin sulfate proteoglycans from embryonic quail that influence neural crest cell behavior. Dev. Biol. 192, 108-124.

Kimata, K., Oike, Y., Tani, K., Shinomura, T., Yamagata, M., Uritani, M. and Susuki, S. (1986). A large chondroitin sulfate proteoglycan (PG-M) synthesized before chondrogenesis in the limb bud of the chick embryo. $J$. Biol. Chem. 261, 13517-13525.

Krull, C. E., Collazo, A., Fraser, S. E. and Bronner-Fraser, M. (1995). Segmental migration of trunk neural crest: time-lapse analysis reveals a role for PNA-binding molecules. Development 121, 3733-3743.

Landolt, R. M., Vaughan, L., Winterhalter, K. H. and Zimmermann, D. R. (1995). Versican is selectively expressed in embryonic tissues that act as barriers to neural crest cell migration and axon outgrowth. Development 2303-2312

Min, H. and Cowman, M. K. (1986). Combined Alcian blue and silver staining of glycosaminoglycans in polyacrylamide gels: application to electrophoretic analysis of molecular weight distribution. Anal. Biochem. 155, 275-285.

Miura. R., Aspberg, A., Ethel, I. M., Hagihara, K., Schnaar, R. L., Ruoslahti, E. and Yamaguchi, Y. (1999). The proteoglycan lectin domain binds sulfated cell surface glycolipids and promotes cell adhesion. J. Biol. Chem. 274, 11431-11438.

Mjaavedt, C. H., Yamamura, H., Capehart, A. A., Turner, D. and Markwald, R. R. (1998). The Cspg2 gene, disrupted in the hfd mutant, is required for the right cardiac chamber and endocardial cushion formation. Dev. Biol. 202, 56-66.

Mörgelin, M., Engel, J., Heinegård, D. and Paulsson, M. (1992) Proteoglycans from the Swarm rat chondrosarcoma. Structure of the aggregates extracted with associative and dissociative solvents as revealed by electron microscopy. J. Biol. Chem. 267, 14275-14284.

Mörgelin, M., Paulsson, M., Malmström, A. and Heinegård, D. (1989). Shared and distinct structural features of interstitial proteoglycans from different bovine tissues revealed by electron microscopy. J. Biol. Chem. 264, 12080-12090.

Morita, H., Takeuchi, T., Susuki, S., Maeda, M., Yamada, K., Eguchi, G. and Kimata, K. (1990). Aortic endothelial cells synthesize a large chondroitin sulphate proteoglycan capable of binding to hyaluronate. Biochem. J. 265, 61-68.

Newgreen, D. F. (1989). Physical influences on neural crest cell migration in avian embryos: contact guidance and spatial restriction. Dev. Biol. 131, 136148 .

Oakley, R:A., Lasky, C. J., Erickson, C. A. and Tosney, K. W. (1994). Glycoconjugates mark a transient barrier to neural crest migration in the chick embryo. Development 120, 103-114.

Oettinger, H. F., Thal, G., Sasse, J., Holtzer, H. and Pacifici, M. (1985) Immunological analysis of notochord and cartilage matrix development with antisera to cartilage matrix macromolecules. Dev. Biol. 109, 63-71.

Olsson, L., Svensson, K. and Perris, R. (1996). Effects of extracellular matrix molecules on subepidermal neural crest cell migration in wild type and white mutant (dd) axolotl embryos. Pigment Cell Res. 9, 18-27.

Perides, G., Asher, R. A., Lark, M. W., Lane, W. S., Robinson, R. A. and Bignami, A. (1996). Glial hyaluronate-binding protein: a product of metalloproteinase digestion of versican ? Biochem. J. 312, 377-384

Perides, G., Rahemtulla, F., Lane, W. S., Asher, R. A. and Bignami, A. (1992). Isolation of a large aggregating proteoglycan from human brain. $J$. Biol. Chem. 267, 23883-23887.

Perris, R. (1997). The extracellular matrix in neural crest cell migration. TINS 20, 23-31.
Perris, R. and Johansson, S. (1987). Amphibian neural crest cell migration on isolated extracellular matrix components: a chondroitin sulfate proteoglycan inhibits locomotion on fibronectin substrates. J. Cell Biol. 105, 2511-2521.

Perris, R. and Johansson, S. (1989). Inhibition of aggregating chondroitin sulfate proteoglycans is mediated by their hyaluronan-binding region. Dev. Biol. 137, 1-12.

Perris, R., Krotoski, D. and Bronner-Fraser, M. (1991b). Collagens in avian neural crest development: distribution in vivo and migration-promoting ability in vitro. Development 113, 969-984.

Perris, R., Krotoski, D., Lallier, T., Domingo C., Sorrel, M., BronnerFraser, M. (1991a). Spatial and temporal changes in the distribution of proteoglycans during avian neural crest development. Development 11, $583-$ 599

Perris, R., Kuo, H. J., Glanville, R. W., Leibold, S. and Bronner-Fraser, M. (1993). Neural crest cell interaction with type VI collagen is mediated by multiple cooperative binding sites within triple-helix and globular domains. Exp. Cell Res. 209, 103-117.

Perris, R., Löfberg, J., Fällström, C., von Boxberg, Y., Olsson, L. and Newgreen, D. F. (1990). Structural and compositional divergencies in the extracellular matrix encountered by neural crest cells in the white mutant axolotl embryo. Development 109, 553-551.

Perris, R., Perissinotto, D., Pettway, Z., Bronner-Fraser, M., Mörgelin, M and Kimata, K. (1996). Inhibitory effects of PG-H/aggrecan and PGM/versican on avian neural crest cell migration. FASEB J. 10, 293-301.

Pettway, Z., Domowicz, M., Schwartz, N. B. and Bronner-Fraser, M. (1996). Age-dependent inhibition of neural crest migration by the notochord correlates with alterations in the S103L chondroitin sulfate proteoglycan. Exp. Cell Res. 225, 195-206.

Pettway, Z., Guillory, G. and Bronner-Fraser, M. (1990). Absence on neural crest cells from the region surrounding implanted notochords in situ. Dev. Biol. 142, 335-345.

Schmalfeldt, M., Dours-Zimmermann, M. T., Winterhalter, K. H. and Zimmermann, D. (1998). Versican $V_{2}$ is a major extracellular matrix component of the mature bovine brain. J. Biol. Chem. 273, 15758-15764.

Shinomura, T., Kimata, K., Oike, Y., Noro, A., Hirose, N., Tanabe, K. and Suzuki S. (1983). The occurrence of three different proteoglycan species in chick embryo cartilage. J. Biol. Chem. 15, 9316-9322.

Shinomura, T., Nishida, Y., Ito, K. and Kimata, K. (1993). cDNA cloning of PG-M, a large chondroitin sulfate proteoglycan expressed during chondrogenesis in chick limb buds. Alternative spliced multiforms of PGM and their relationship to versican. J. Biol. Chem. 268, 14461-14469.

Shinomura, T., Zako, M., Ito, K., Uijta, M. and Kimata, K. (1995). The gene structure and organization of mouse PG-M, a large chondroitin sulfate proteoglycan. Genomic background for the generation of multiple PG-M transcripts. J. Biol. Chem. 270, 10328-10333.

Sorrell, J. M., Carrino, D. A. and Caplan, A. I. (1993). Structural domains in chondroitin sulfate identified by anti-chondroitin sulfate monoclonal antibodies. Immunosequencing of chondroitin sulfates. Matrix 13, 351361

Stern, C. D., Artinger, K. B. and Bronner-Fraser, M. (1991). Tissue interactions affecting the migration and differentiation of neural crest cell in the chick embryo. Development 113, 207-216.

Stigson, M. and Kjellén, L. (1991). Large disulfide-stabilized proteoglycans complexes are synthesized by the epidermis of axolotl embryos. Arch. Biochem. Biophys. 290, 391-396.

Stigson, M., Löfberg, J. and Kiellén, L. (1996). PG-M/versican-like proteoglycans are components of large disulfide-stabilized complexes in the axolotl embryo. J. Biol. Chem. 272, 3246-3253.

Stigson, M., Löfberg, J. and Kjellén, L. (1997). Reduced epidermal expression of a PG-M/versican-like proteoglycan in embryos of the white mutant axolotl. Exp. Cell Res. 236, 57-65.

Tan, S. S., Crossin, K. L., Hoffman, S. and Edelman, G. M. (1987). Asymmetric expression in somites of cytotactin and its proteoglycan ligand is correlated with neural crest cell distribution. Proc. Natl. Acad. Sci. USA 84, 7977-7981.

Teillet, M. A. and Le Douarin, N. M. (1983). Consequences of neural tube and notochord excision on the development of the pereipheral nervous system in the chick embryo. Dev. Biol. 98, 192-211.

Tosney, K. W. and Oakley, R. A. (1990). The perinotochordal mesenchyme acts as a barrier to axon advance in the chick embryo: implications for a general mechanism of axonal guidance. Exp. Neurol. 109, 75-89.

Wilkinson, D. G. (1992). In Situ Hybridization: A Practical Approach Oxford, UK: IRL Press. 
Yamagata, M., Shinomura, T. and Kimata, K. (1993). Tissue variation of two large chondroitin sulfate proteoglycans (PG-M/versican and PGH/aggrecan) in chick embryos. Anat. Embryol. 187, 433-444.

Yamagata, M., Yamada, K. M., Yoneda, M., Suzuki, S. and Kimata, K. (1986). Chondroitin sulfate proteoglycan (PG-M-like proteoglycan) is involved in the binding of hyaluronic acid to cellular fibronectin. J. Biol. Chem. 261, 13526-13535.

Yao, L. Y., Moody, C., Schönherr, E., Wight, T. N. and Sandell, L. J. (1996). Identification of the proteoglycan versican in aorta and smooth muscle cells by DNA sequence analysis, in situ hybridization and immunohistochemistry. Matrix Biol. 14, 213-225.

Zako, M., Shinomura, T. and Kimata, K. (1997). Alternative splicing of the unique 'PLUS' domain of chicken PG-M/versican is developmentally regulated. J. Biol. Chem. 272, 9325-9331.

Zako, M., Shinomura, T., Uijta, M., Ito, K. and Kimata, K. (1995). Expression of PG-M(V3), an alternatively spliced form of PG-M without a chondroitin sulfate attachment region in mouse and human tissues. J. Biol. Chem. 270, 3914-3918. 